Perspective

\title{
Exploring the Impact of Climate Change on Arctic Shipping through the Lenses of Quadruple Bottom Line and Sustainable Development Goals
}

\author{
Stephen J. Tiller 1,2, Adam P. Rhindress ${ }^{2,3}$, Ibrahim O. Oguntola ${ }^{2,4}$, M. Ali Ülkü 2,3,4,*(D, Kent A. Williams ${ }^{2,3}$ \\ and Binod Sundararajan 2,3
}

1 Marine Affairs Program, Faculty of Science, Dalhousie University, Halifax, NS B3H 4R2, Canada; stephen.tiller@dal.ca

2 CRSSCA-The Centre for Research in Sustainable Supply Chain Analytics, Dalhousie University, Halifax, NS B3H 4R2, Canada; adamrhindress@dal.ca (A.P.R.); ibrahim.oguntola@dal.ca (I.O.O.); kent.williams@dal.ca (K.A.W.); binod@dal.ca (B.S.)

3 Rowe School of Business, Dalhousie University, Halifax, NS B3H 4R2, Canada

4 Department of Industrial Engineering, Dalhousie University, Halifax, NS B3H 4R2, Canada

* Correspondence: ulku@dal.ca

\section{check for} updates

Citation: Tiller, S.J.; Rhindress, A.P.; Oguntola, I.O.; Ülkü, M.A.; Williams, K.A.; Sundararajan, B. Exploring the Impact of Climate Change on Arctic Shipping through the Lenses of Quadruple Bottom Line and Sustainable Development Goals. Sustainability 2022, 14, 2193. https:// doi.org/10.3390/su14042193

Academic Editors: Oran Young and Robert Orttung

Received: 22 December 2021

Accepted: 8 February 2022

Published: 15 February 2022

Publisher's Note: MDPI stays neutral with regard to jurisdictional claims in published maps and institutional affiliations.

Copyright: (C) 2022 by the authors. Licensee MDPI, Basel, Switzerland. This article is an open access article distributed under the terms and conditions of the Creative Commons Attribution (CC BY) license (https:// creativecommons.org/licenses/by/ $4.0 /)$.

\begin{abstract}
Climate change is everywhere, and the Arctic is no exception. The melting sea ice has caused renewed interest in expanding maritime shipping for potentially more accessible ocean routes. Canada emerges as a natural land bridge for trade between Asia, Europe, and the Americas. Plausibly, it is not a choice but an imperative to properly integrate the stakeholders (the environment, countries, remote communities, industrial partners) in opening the Arctic Circle to the global economy while considering the challenges. Keeping sustainability front and center and drawing on the extant literature and government policies, this interdisciplinary study offers a Canadian perspective on Arctic transportation routes over tribal lands and their quadruple bottom line (QBL) impacts on the environment, economy, society, and Indigenous cultures. Unlike the arguable premise that new transport corridors will increase trade traffic and enhance the economy in Northern Canada, the QBL approach enables a more holistic and realistic strategy for the Arctic region's sustainable development regarding regional economies, rural logistics, supply chain efficiency, and social licensing. Drawing on an integrative literature review as methodology, we highlight the QBL framework and the United Nations Sustainable Development Goals as crucial policy tools. Such a holistic perspective helps stakeholders and decision makers frame better policies in identifying, assessing, adapting, and mitigating risks for transportation infrastructure exposed to climate change. We recap the impacts of Arctic Shipping (ArSh) on QBL pillars in an interaction matrix and emphasize that while ArSh may be complementary to economic development, it poses threats to the viability of the Indigenous cultures.
\end{abstract}

Keywords: climate change; sustainability; Arctic shipping; Canada; Indigenous communities; rural logistics and supply chains; culture; sustainable economic development

\section{Introduction}

The idea of utilizing the Arctic Ocean for marine shipping has gained momentum in recent decades. What was once a theoretical aspiration is now turning into a potential reality due to economic opportunities, enhanced ship design and technology, and climate change accelerating sea ice melt, all leading to more navigable waterways [1]. Climate studies suggest that the Arctic is warming almost three times quicker than regions at lower latitudes, creating an influx of nations looking toward the Arctic to expand trade routes [2]. As a result, Canada's Arctic has seen the distance travelled by ships in the region triple since 1990, with numbers projected to rise. Impacting Arctic communities and cultures, 
most of the shipping increase has been from domestic transits such as community resupply, government and private icebreakers, pleasure craft, and fishing vessels [3,4]. Current projections are that the Northwest Passage (NWP) will become available for maritime shipping up to six months of the year in the coming decades, and by 2100 , year-round travel could be possible [5,6]. Regardless of the speed of sea ice depletion, the increase in Arctic Shipping (ArSh, hereafter) will likely continue. The future of the planet depends greatly on sustainability-based initiatives and ArSh is simply another area where sustainability is critical to success.

While there is an influx of domestic shipping into Canada's Arctic, a greater amount of global trade transport may be on the near horizon due to the emergence of Canada's Arctic as a trade route from Europe and Asia to the Americas. In past centuries, the NWP was mainly impassable due to thick year-round sea ice [7]. However, in recent years, accessibility has improved for commercial traffic, primarily because of climate change and ship enhancements: There are inarguable benefits to utilizing the NWP as an international trade route compared to traditional routes such as the Panama or Suez Canal. From major exporting countries in Asia to large importing countries in Europe, routes are over $4000 \mathrm{~km}$ shorter through the NWP than via the Suez Canal route [8]. Shipping firms and trading nations may save time and money per transit, leading to quicker product supply and decreased shipping costs. In 2013, the bulk carrier Nordic Orion traversed the NWP, shortening its journey by four days and saving approximately $\$ 200,000$ [9]. Furthermore, the NWP route would reduce greenhouse gas (GHG) emissions, thus helping countries meet their Paris Agreement and United Nations Sustainable Development Goals (UNSDGs; in short, SDGs, hereafter). Besides, northern communities could see economic benefits such as infrastructure development and communications access [10].

A broad range of literature has been produced that demonstrates the pros and cons of shipping through the NWP. However, there is little about a Canadian perspective on Arctic transportation routes through quadruple bottom line (QBL) impacts on the environment, economy, society, and Indigenous cultures (Ülkü and Engau, 2021 [11]). In this paper, we ask the following question: what are the implications of ArSh for $Q B L$ sustainability and their relation to SDGs? Our methodology involves an integrative literature review, relating QBL pillars to SDGs by way of examples from Canada, and finally developing an interaction matrix in which the impacts of ArSh on QBL pillars are categorized. We posit that although shipping through Canada's Arctic offers an array of benefits, conflicts may arise without proper mitigation strategies and management frameworks. This study aims to inform scholars, policymakers, supply chain risk analysts, and managers of the Canadian QBL implications of ArSh before enacting the next steps for sustainable strategies and actions. The paper considers an array of stakeholders, geographic areas, and management frameworks for risk analysis in the Arctic (c.f., [12]).

The layout of this paper is organized as follows: Section 2 provides the context, methodology, and contribution of this study in comparison to the recent literature (see Table 1). Section 3 and its subsections analyze the implications of Canadian ArSh on each QBL pillar: the economy, environment, society, and Indigenous cultures. In Section 3.5, we recap the results of our study and summarize our findings in a matrix that displays the various conflicting and complementary interactions of ArSh in Canada. Section 4 provides further discussions and debriefs implications. Finally, we conclude in Section 5 and give further research venues. 
Table 1. An overview of the literature on Arctic Shipping (ArSh) related to QBL.

\begin{tabular}{|c|c|c|c|c|c|c|c|c|}
\hline \multirow[b]{2}{*}{ Papers Compared } & \multicolumn{4}{|c|}{ QBL Pillars } & \multicolumn{4}{|c|}{ Approach/Methodology } \\
\hline & 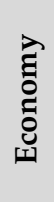 & 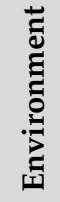 & 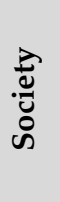 & 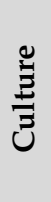 & & 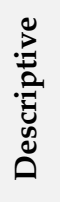 & 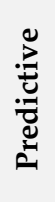 & : \\
\hline Corbett et al. [13] & & $\checkmark$ & & & $\checkmark$ & & $\checkmark$ & \\
\hline Smith and Stephenson [14] & $\checkmark$ & $\checkmark$ & & & $\checkmark$ & & & \\
\hline Buixadé Farré et al. [15] & $\sqrt{2}$ & $\checkmark$ & & & & $\checkmark$ & & \\
\hline Lu et al. [6] & $\checkmark$ & & & & $\checkmark$ & & $\checkmark$ & $\checkmark$ \\
\hline Miller and Ruiz [16] & & $\checkmark$ & & & & $\checkmark$ & $\checkmark$ & \\
\hline Ghosh and Rubly [17] & & $\checkmark$ & & & & $\checkmark$ & & $\sqrt{ }$ \\
\hline Champalle et al. [18] & & & $\checkmark$ & $\checkmark$ & & & & $\checkmark$ \\
\hline Halliday et al. [19] & & $\checkmark$ & & & $\checkmark$ & & $\checkmark$ & \\
\hline Theocharis et al. [20] & $\checkmark$ & $\checkmark$ & & & & $\checkmark$ & & \\
\hline Ng et al. [21] & $\checkmark$ & $\checkmark$ & $\sqrt{ }$ & & $\checkmark$ & & $\checkmark$ & \\
\hline Downing [22] & & $\checkmark$ & & $\checkmark$ & & $\checkmark$ & & \\
\hline Our Paper & $\checkmark$ & $\checkmark$ & $\checkmark$ & $\checkmark$ & $\checkmark$ & $\checkmark$ & $\checkmark$ & \\
\hline
\end{tabular}

\section{Context, Methodology, and Contribution}

The context of this study emanates from three terms: Arctic shipping (ArSh), quadruple bottom line, and SDGs. The ArSh routes connect the Pacific and the Atlantic Ocean, cutting through the Canadian Arctic Archipelago (see Figure 1). Over the past decade, the use of ArSh routes has increased significantly as climate change has caused a decline in sea ice, which is expected to continue. The idea that ArSh could be the way of the future has been predicted for some time. Although the benefits of trans-ArSh are clear, it would be folly to ignore the impacts that shipping in the NWP will inevitably generate. In recent years, there has been a growing demand for sustainable development (SD) in business activities, primarily derived from the realization that without a protected biosphere, there is no economy and society to build [23]. As a result, many corporations seek to transition from singular bottom-line accounting to the more holistic approach of the quadruple bottom line (QBL). QBL incorporates environment, economy, and society from the triple bottom line approach, but with the addition of a fourth pillar: culture. An ever-evolving term, culture's dictionary definitions include "the customary beliefs, social forms, and material traits of a racial, religious, or social group" (e.g., Aboriginal culture), and "the set of shared attitudes, values, goals, and practices that characterizes an institution or organization" such as business culture (see, ref. [24] for definition).

As depicted in Figure 2, from a QBL perspective, the environment enables societies to exist and thrive, whereas the economy is a creation of and would not exist without society. Culture, as we understand it in this study, buttresses both societal well-being and economic prosperity. For instance, a region might have strong economic indicators, but if it is plagued with corrupt business culture, that economic prosperity is destined to collapse. Similarly, a big infrastructure investment, such as highways through tribal lands, may impact the native communities and their cultural viability. With sustainability-based incentives, the United Nations created a blueprint to achieve a more sustainable future by 2030; we link the 17 SDGs (see, [25]) to QBL pillars in the remainder of this paper. These SDGs namely are \#1, No poverty; \#2, Zero hunger; \#3, Good health and well-being; \#4, Quality education; \#5, Gender equality; \#6, Clean water and sanitation; \#7, Affordable and clean energy; \#8, Decent work and economic growth; \#9, Industry, innovation, and infrastructure; \#10, Reduced inequalities; \#11, Sustainable cities and communities; \#12, Responsible consumption and production; \#13, Climate action; \#14, Life below water; \#15, Life on land; \#16, Peace, justice and strong institutions; and finally, \#17, Partnerships for the goals. The 2030 SDGs agenda aims to transform our world by setting specific goals 
to be achieved by humankind to ensure environmental protection, economic prosperity, and societal well-being and these goals naturally interact with each other (e.g., [26]), which makes it difficult to improve solely on a single goal. For example, SDG\#6, clean water and sanitation, has direct implications on the environment, which in turn impacts the society (human health) and ultimately the economy. As emphasized in [27], achieving SDGs calls for prompt and honest policies and actions by companies in the marketplace. Most of the 17 SDGs are highly relevant and have implications for ArSh, demonstrating the timely relevance of this topic.

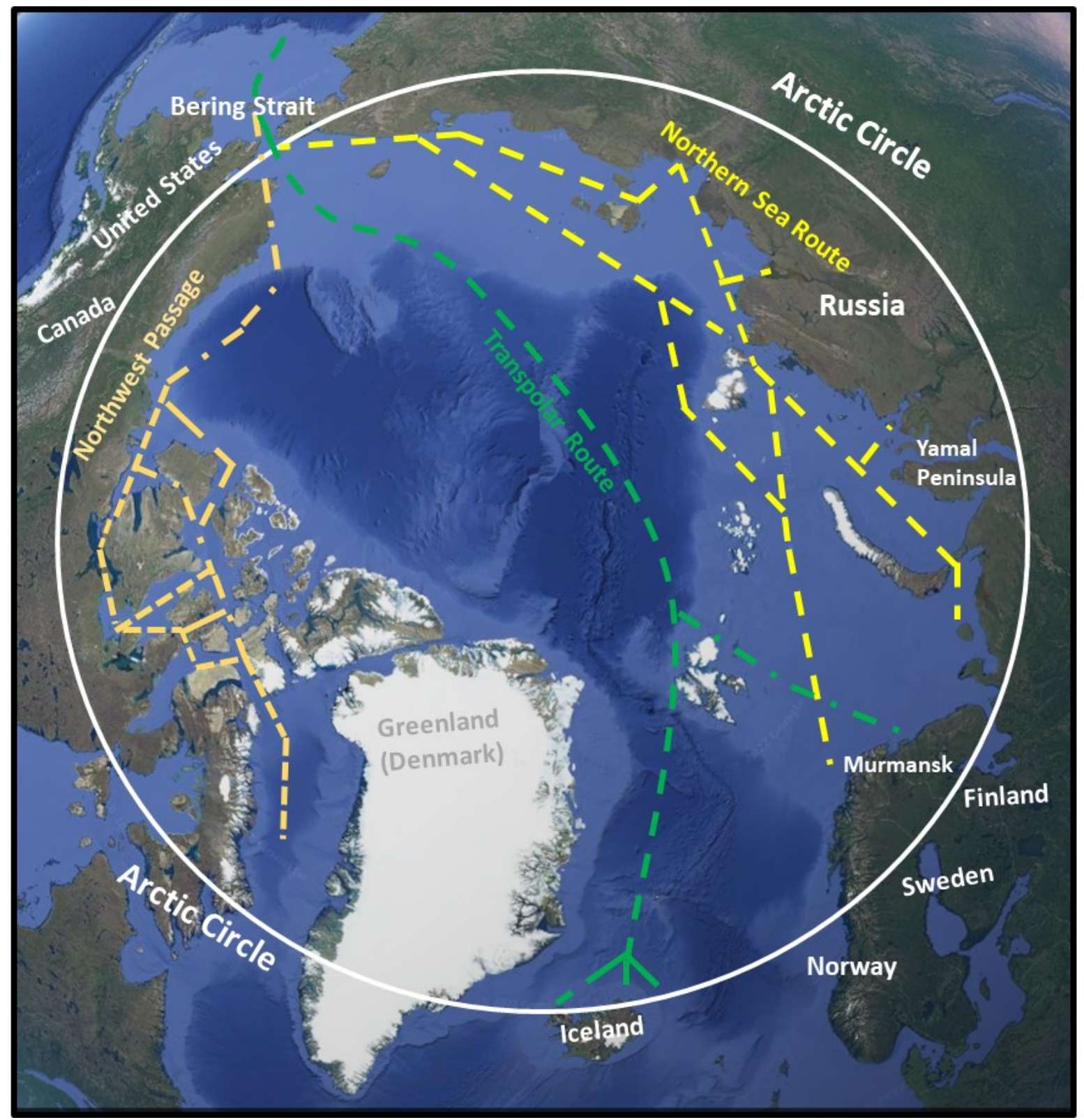

Figure 1. Arctic Shipping (ArSh) routes: Northwest Passage, Transpolar Route, Northern Sea Route.

The QBL framework has become increasingly prevalent in different aspects of business, including transportation. As stated above in [11], in studying sustainable supply chain management, suggested the addition of a fourth pillar: culture. Literature on the QBL perspective in business is still in its infancy; unlike the true cultural approach (e.g., [28-30]), few studies take "governance" as the fourth pillar (e.g., [31]).

Our unique QBL and SDG approach to Arctic marine transportation utilizes an integrative literature review as the methodology of this study (c.f., [32,33]) and our analysis is 
qualitative. In classifying studies for each QBL pillar, we used Google Scholar to identify the largest possible pool of publications (journal articles and books). The search terms used were "Arctic shipping/transportation and sustainable/sustainability." There were 1180 publications during 2010-2015 with these keywords in the title or the abstract, which has almost doubled (2320) for 2016-2021. Such an increase shows that academic interest has been piqued and that sustainable plans are needed for Arctic shipping. The pool of publications during the last decade was narrowed by adding the keyword "SDG", resulting in 243 publications; these publications were then reviewed and filtered with the condition that they significantly study at least one of the QBL pillars and/or a combination of methodological approaches. Finally, 11 papers were chosen to form the basis of our integrative literature review from which we identify the gap in knowledge, and therefore the contribution of this paper (see Table 1). Those articles with a close relation to ArSh via only one or two pillars of QBL are discussed in Section 3. We also considered grey literature such as the United Nations technical reports and credible news pieces to further motivate the importance of ArSh and the critical issues surrounding it.

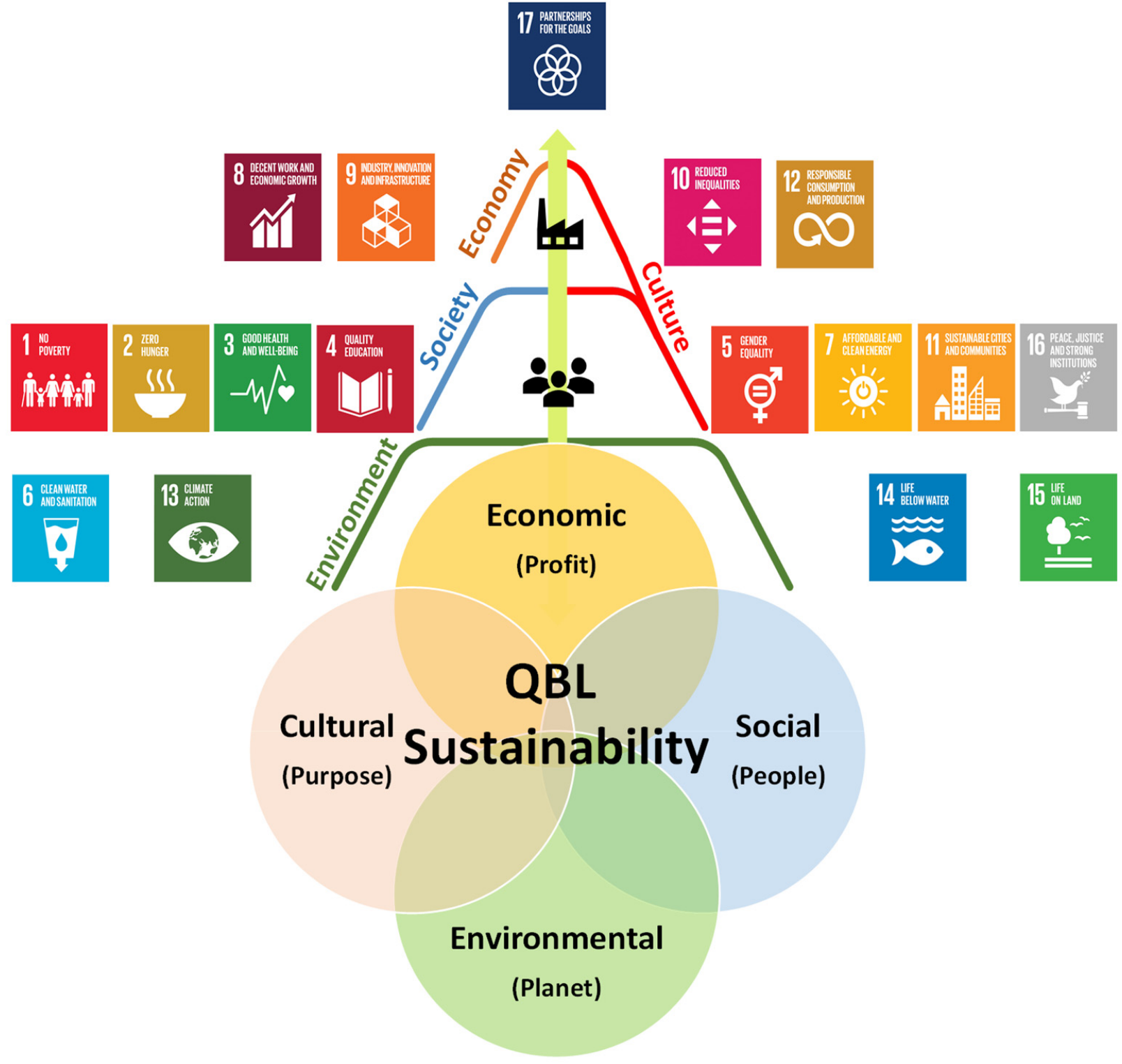

Figure 2. Framework-Quadruple bottom line (QBL) pillars and the SDGs. 
Theocharis et al. [20] found that ArSh appeared in academic literature as early as 1980, but research has increased significantly in the past decade. Much of the recent literature focuses on the economic and environmental implications of increased Arctic shipping, particularly on costs and emissions; research on the social and cultural implications has been limited, calling for a need for collaborative governance [34].

The major contribution of this paper lies in synthesizing the sustainability issues of ArSh through the lens of the SDGs and the QBL pillars. Justifiably, studies oriented towards SDGs in all academic disciplines, and especially in business, are increasing (e.g., [35]). However, a significant gap in the literature exists in analyzing the implications these pillars have on one another and viewing the situation from a holistic Canadian QBL perspective. Table 1 includes a collection of academic literature on the topic of ArSh categorized by the QBL pillars discussed as well as the approach used by the researchers. As indicated, our exploratory study aims to address the implications of each of the four QBL pillars using a descriptive and predictive approach. To the best of the authors' knowledge, there have been no studies published to date on increased ArSh from the perspectives of the QBL and SDGs, which is the gap in the literature this paper seeks to address.

Earlier studies suggesting that Arctic Sea routes were a possibility mostly focused on feasibility. The literature has mixed conclusions on whether increased ArSh will be sustainable. For instance, Corbett et al. [13] suggested that increased ArSh would only accelerate climate change resulting in further destruction of Arctic Sea ice than is healthy for the planet. Smith and Stephenson [14] published a pivotal article stating that the new ArSh routes would be navigable by mid-century. Those authors discussed the economic and environmental implications of increased Arctic shipping, determining that there would be significant challenges ahead in both domains.

Buixadé Farré et al. [15] more closely examined the NWP, concluding that conditions in the Arctic were more favourable than ever for marine transportation. Lu et al. [6] analyzed the various routes. They performed an economic analysis on the most advantageous ones, which determined the new routes would be profitable for Canada and the shipping firms that chose to use them. The economic implications discussed in the literature mostly involve costs stemming from fuel consumption, speed, bunker fuel prices, and transit fees [20]. Other common factors considered were the cost of preparing ships for Arctic climate conditions, insurance costs, and legal fees. $\mathrm{Ng}$ et al. [21] examined the environmental and economic feasibility of ArSh and confirmed that significant challenges lay ahead for shipping firms, businesses, and Arctic communities alike. The authors determined that the infrastructure for increased shipping is not yet established in the Arctic and that a robust sustainability framework is required.

As for environmental impact, the most common measure in the literature is carbon emissions. Given the shorter distance ships will need to travel, overall carbon emissions will decrease, benefiting human development and the biosphere. There are, however, other environmental risks to the Arctic, including oil and noise pollution, aquatic species invasion, marine mammal displacement, carbon emissions, and more [17]. Halliday et al. [19] studied the impacts shipping noise will have on marine mammals, concluding that there will be substantial impacts, and this may be a reason to use shipping routes located further North. Miller and Ruiz [16] raised concerns about the conservation and sustainable use of the Arctic environment as marine habitats and ecosystems will undoubtedly be affected. This is concerning because it is already recognized we are in the sixth period of mass species extinction, the fifth being the dinosaurs [36].

Although Arctic shipping's social and cultural implications have not been researched as extensively, the topic is still prevalent in the literature. The Arctic Corridors and Northern Voices (ACNV) research project has published various reports for policy on shipping governance in the Canadian Arctic (see, [37]). Those reports discuss the impacts ArSh will have on various specific Indigenous communities. One report, for example, discusses shipping trends in Nunavut from 1990 to 2015, which is important research to recognize trends and make predictions [3]. The primary issues discussed in the literature regarding 
social and cultural implications are sustainable and peaceful development, food insecurity, impacts on employment, and destruction of land and wildlife.

Champalle et al. [18] suggest a community-driven approach will be necessary as Indigenous knowledge frameworks and land skills are invaluable. More recently, other scholars have published similar findings in their research. Downing [22] emphasizes how increased maritime shipping will completely change the lifestyles of Indigenous populations, and while both positive and negative aspects exist, there is the need for plans and policies that protect these populations.

There is consensus in the literature that ArSh will continue to increase as it has over the past decade. With sea ice melting rapidly, conditions in the Arctic are continually improving for maritime transportation. However, this opportunity comes with negative impacts that need to be critically weighed and considered, as we discuss in the following QBL and SDG analysis.

\section{A QBL and SDG Approach to ArSh}

In positioning our study in the literature and our analysis of key papers, as displayed in Table 1, we showcase, among others, the need for the inclusion of the cultural aspects of sustainability in a holistic framework for decisions relating to ArSh. Next, we provide more specific literature as it relates to each of the QBL pillars.

\subsection{Implications for Economic Sustainability}

The first pillar of the QBL framework we analyze is the economy. The economic benefits of increased ArSh are typically the primary argument for rapid shipping expansion. As transportation through new ArSh routes increases, there will be numerous economic implications for Northern Canadian communities, businesses, shipping firms, and others. As the new routes go through Canadian waters, the economic impacts will be felt by Canada on a national level as well as by other countries that use the route. This will have an economic impact on natural resources, transportation, and trade relations between countries, the extent of which depends on how much the route is used. If projections are correct, there is potential for significant economic gain for Canada, other nations, and firms that use those Arctic routes. The implications of ArSh for economic sustainability integrated with SDGs are summarized in Table 2.

First, the NWP route may be more profitable. Asia and North America are two of the top three world trade areas, with cargo being shipped between the two primarily going through the Panama Canal. Lu et al. [6] developed a formula for estimating the shipping cost of a container ship assuming the NWP is open for international passage and found that the NWP could be financially more advantageous by at least $\$ 600,000$ compared to the Panama Canal. This is in part due to shorter distances. For example, travel between Tokyo and London through the NWP makes the trip 7000 kilometres shorter than it would be through the Panama Canal [38]. This means that transportation costs would be lower through decreased fuel costs, lower salaries for crews due to the shortened trip, and lower overhead costs. In some instances, it has been found that the NWP provides greater shelter from storms compared to the Panama Canal [38]. If this is the case, it could aid in terms of risk management and expenses due to lost or damaged cargo. While the Panama Canal may experience more tropical storms, ArSh does have its unique extreme climate and weather challenges, including floating ice, thick fog, and violent storms [5]. It is common for ships to be damaged by ice in these regions, and the harsh environment can be quite difficult for crews if they are not used to it. These issues are all contributing factors to the expenses of Arctic shipping. Moreover, ArSh is currently only possible during certain months of the year. As seen in Figure 3, the average temperatures in Arctic Bay, Nunavut (which is on the NWP) are currently above freezing only three months of the year. However, if the warming trend continues, year-round travel could be possible by 2100, by which time extreme Arctic conditions may be less damaging (see, [6]). 
Table 2. Summary of economic implications or ArSh with relation to SDGs.

\begin{tabular}{|c|c|c|c|c|c|}
\hline \multirow[b]{2}{*}{ Factors Considered } & \multirow[b]{2}{*}{ Potential Effects from ArSh } & \multicolumn{4}{|c|}{ Related SDGs } \\
\hline & & 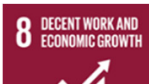 & 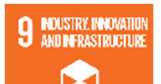 & 10 REDUCED & 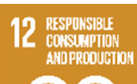 \\
\hline \multirow{2}{*}{$\begin{array}{l}\text { Employment in the } \\
\text { Canadian Arctic }\end{array}$} & $\begin{array}{l}\text { + Higher employment opportunities. } \\
\text { + New industries available. }\end{array}$ & \multirow[b]{2}{*}{$\checkmark$} & \multirow[b]{2}{*}{$\checkmark$} & & \multirow[b]{2}{*}{$\checkmark$} \\
\hline & $\begin{array}{l}\times \text { Traditional forms of } \\
\text { employment-hunting and fishing } \\
\text { are vulnerable. }\end{array}$ & & & & \\
\hline \multirow{2}{*}{$\begin{array}{l}\text { Cargo shipping through } \\
\text { the NWP }\end{array}$} & $\begin{array}{l}\text { + Reduced transport costs for shipping } \\
\text { firms who use this shorter route. } \\
\text { + Wider area allows large cargo ships. } \\
\text { + Greater shelter from storms. }\end{array}$ & \multirow{2}{*}{$\checkmark$} & & & \multirow{2}{*}{$\checkmark$} \\
\hline & $\begin{array}{l}\times \text { Poor weather conditions could } \\
\text { increase product loss \& damage. } \\
\times \text { Cost of preparing for Arctic } \\
\text { weather conditions. }\end{array}$ & & & & \\
\hline \multirow[t]{2}{*}{$\begin{array}{l}\text { Economic growth for } \\
\text { Canada and the } \\
\text { Canadian Arctic }\end{array}$} & $\begin{array}{l}\text { + Opportunity for Canada to charge a toll } \\
\text { for users of the NWP. } \\
\text { + Improved trade relations with other } \\
\text { nations that use the route. } \\
\text { + Potential for population growth in } \\
\text { Northern Canada. }\end{array}$ & \multirow[t]{2}{*}{$\checkmark$} & & \multirow[t]{2}{*}{$\checkmark$} & \\
\hline & $\begin{array}{l}\times \text { Natural environment may be } \\
\text { damaged, depleting natural resources. }\end{array}$ & & & & \\
\hline \multirow[t]{2}{*}{$\begin{array}{l}\text { Infrastructure update in } \\
\text { the Canadian Arctic }\end{array}$} & $\begin{array}{l}\text { + The Arctic will become less remote and } \\
\text { more profitable. } \\
\text { + Greater access to emergency and safety } \\
\text { services in the Arctic. }\end{array}$ & \multirow[t]{2}{*}{$\checkmark$} & \multirow[t]{2}{*}{$\checkmark$} & \multirow[t]{2}{*}{$\checkmark$} & \\
\hline & $\begin{array}{l}\times \text { Wildlife may be hurt due to a } \\
\text { damaged natural environment. }\end{array}$ & & & & \\
\hline
\end{tabular}

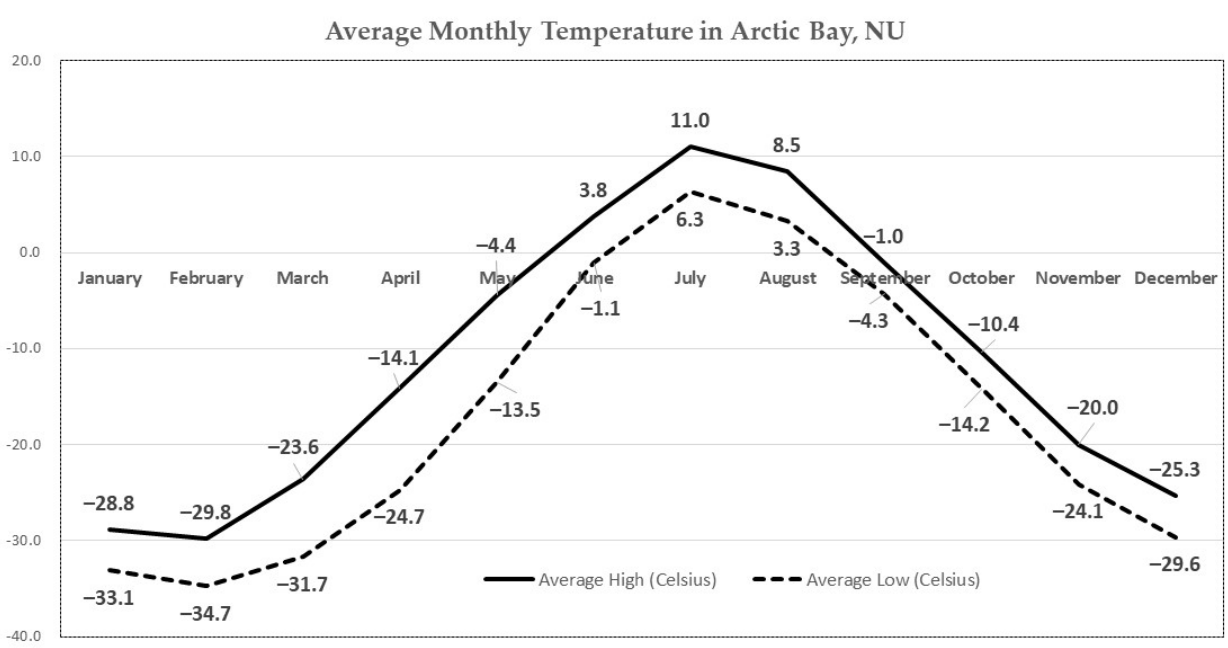

Figure 3. The average temperature in Arctic Bay, Nunavut, Canada by month (data source: [39]).

There will be economic benefits for certain Northern Canadian communities that will be directly affected by ArSh; for instance, demand for supplies will increase. This means that Northern communities would have financial incentives to develop businesses near the 
NWP. There may be an increased need for emergency shelters, supply warehouses, and rescue teams. For example, for some time, it has been suggested that some ports such as Tuktoyaktuk and Iqaluit would emerge as major Canadian ports in the future [41] with enhanced regional economic developments. Currently, Canada has 17 Port Authorities based on their strategic, regional, national, continental, and international importance. In 2017 , Canada's ports brought in a total of $\$ 110$ billion - $21 \%$ of Canada's total imports by value [42]. Given that ports are such a large portion of Canada's import revenues, it is likely that Arctic Canadian ports will become much more important as ArSh increases.

As the NWP is used more frequently, there may come the threat of increased illegal activities such as smuggling and trafficking. There may also be more marine traffic accidents and threats that require increased Arctic surveillance, search and rescue, policing, and environmental regulation enforcement [43]. Because of this, many Northern Canadian communities may see a demand for employees, but at the expense of taxpayer dollars. The Canadian Arctic makes up $40 \%$ of the country's landmass, but less than $1 \%$ of the population lives there [44]. The expansion of shipping through the NWP could create an incentive for more Canadians to move to northern areas of the country and further utilize Canada's natural resources, resulting in economic growth. Although the cost of living is high in Northern Canada, increased usage of these regions could lead to higher salaries, and additionally, the availability of supplies coming in via the new northern ports could reduce the cost-of-living expenses.

There are some potentially negative economic implications of increased ArSh that should be discussed. For instance, there is the risk that Indigenous communities could lose or have diminished ability to hunt for their traditional food sources. When fish, animals, and marine mammals are disturbed by increased ship traffic, they will abandon their regular habitat. Given the remoteness of the Arctic, many individuals rely on hunting for food, and the impacted wildlife could cause them to have to go further, hunt in unfamiliar places, and be away from their families for longer periods. Furthermore, if hunters are unsuccessful, they may be forced to buy overpriced shipped food from grocery stores, which would hurt them financially and culturally (discussed more in Section 3.4). Many hunters rely on income from selling skins, meat, and tusks [37]. With decreased or more difficult access to hunting, Arctic hunters could experience a decrease in income, but more importantly a way of living, leading to exploring other means of livelihood, which may not be readily available.

Another potential economic implication, primarily for container or cruise shipping companies, would be the additional cost of surveying ships (but a benefit to surveying companies) to ensure they can sail through ice-covered areas. As previously stated, Arctic waters may not be passable year-round for many decades to come, and when they are, there will still be ice. In addition to sea ice and extremely low temperatures, weather conditions are worsened further by high latitude and remoteness [5]. For this reason, the Polar Code was established to address the risks of Arctic waters, ensure ships are following safety procedures, and protect the environment. To become certified under the Polar Code, ships must be surveyed in terms of structure, equipment, and materials and are then assigned to one of three categories (A, B, or C) based on the kind of ice conditions (if any) they can handle [45]. For safety reasons, ships are required to have formal procedures in place given the risks of the Arctic. It will not be a small task for ships to become certified and adjust to Arctic shipping, and this cost should be considered. As time goes on, however, this will be less of a concern as companies adjust to the process.

Finally, there are severe environmental impacts of increased transportation in the NWP (further discussed in Section 3.2). Given that climate change is a growing issue, there is a need to mitigate some of the adverse effects on the environment and the planet. This has the potential to be quite costly and therefore is another economic impact of increased Arctic shipping. Some examples of costs that could arise from environmental issues or environmental risk mitigation include oil spillage cleanup, pollution or waste reduction, 
and wildlife protection. Environmental policies must be developed and updated as well as enforced.

Overall, ArSh may bring significant economic benefit to Canada, specifically to the communities on the Arctic coastline. This is also true for shipping companies and businesses in many areas of the globe that can take advantage of the new routes. From an economic perspective, one may argue that Canadian ArSh routes appear economically feasible and sustainable given that they seem to align with the applicable SDGs. The SDGs that are directly related to the economy are (\#8) decent work and economic growth, (\#9) industry innovation and infrastructure, (\#10) reduced inequalities, and (\#12) responsible consumption and production. Based on the studies we discussed above and the current efforts by the Canadian and other governments to ensure better and safer shipping through the NWP, we interpret and infer that the "potential effects" of ArSh via the NWP can have both positive and negative lasting economic implications for the Canadian economy in general and the communities that live in these regions.

\subsection{Implications for Environmental Sustainability}

Studies have shown that ArSh could be advantageous by the reduction of the carbon footprint as less fuel is consumed and shorter transportation distances [46,47]. Figure 4 shows a case study of a cargo voyage from Yokohama, Japan, to Hamburg, Germany. The duration and the fuel consumed while transiting the Suez Canal, NWP, Northern Sea Route (NSR) routes are compared. The study by Weregeland [48] suggests the NWP route provides a significantly shorter travel time ( 25 days) and less fuel consumption (528 tons) than the currently more utilized Suez Canal (34 days, 838 tons). The NSR route also requires less travel time ( 23 days) and fuel consumption ( 479 tons). Another study was conducted with a sample trip from Shanghai, China, to Hamburg, Germany, using a container ship. The trip through the NWP provides a similar travel time (19 days) but significantly less fuel consumption (1994 tons) than the currently more utilized Suez Canal (19 days, 3275 tons).

Consequently, if more ships were to transit the NWP as an alternative to the Suez Canal, total savings on fuel would accumulate, potentially leading to reductions in total global GHG emissions and less impact on the biosphere. Nevertheless, the additional fuel consumption of icebreakers (if need be) must be included for precise comparison. In assessing the environmental sustainability of shipping through the Canadian Arctic, the activities must align with the SDGs, which include preservation of clean water and sanitation (\#6), reduced or sustainable impacts on climate (\#13), harmlessness to life below water (\#14) and life on land (\#15). With this in mind, we assess such factors as exhaust emissions from shipping, risk of oil spills, noise pollution, and ship strikes, and we summarize in Table 3 their implications for environmental sustainability and relationships to SDGs.
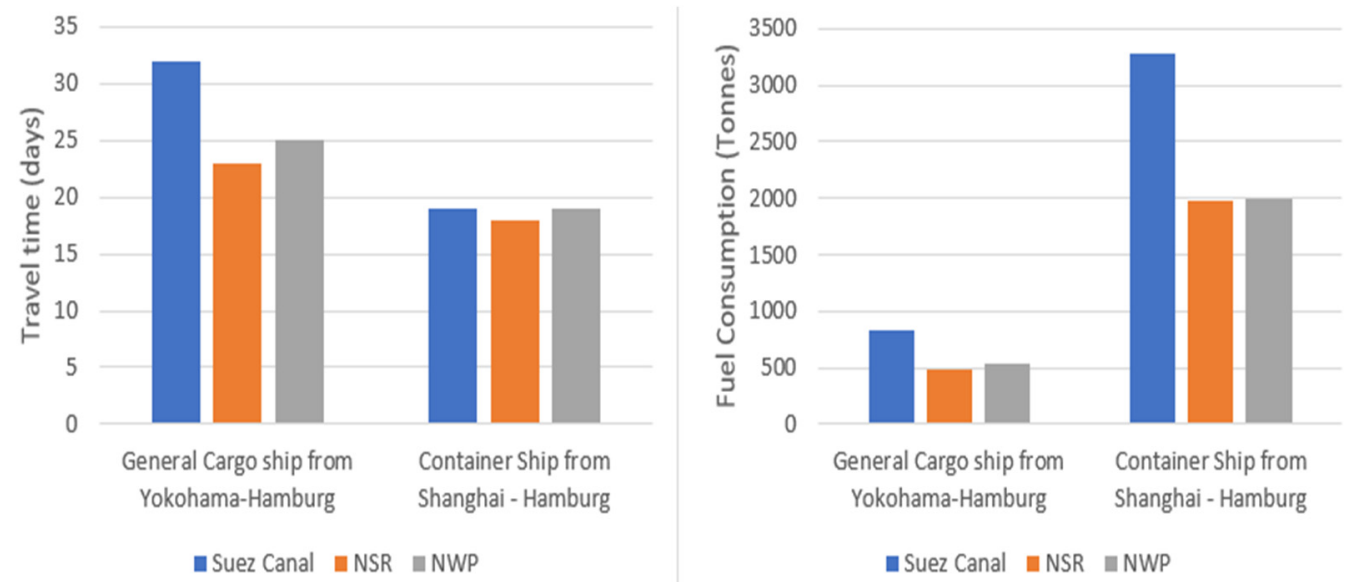

Figure 4. Duration (days) and fuel consumption (a proxy for GHG emissions) of cargo ship via the Suez Canal, NSR, and NWP comparison (data source: [48]). 
Table 3. Summary of environmental implications of ArSh with relation to SDGs.

\begin{tabular}{|c|c|c|c|c|c|c|}
\hline \multirow[b]{2}{*}{$\begin{array}{l}\text { Factors } \\
\text { Considered }\end{array}$} & \multirow[b]{2}{*}{ Samples of Hazards } & \multirow[b]{2}{*}{$\begin{array}{l}\text { Potential Effects from } \\
\text { ArSh }\end{array}$} & \multicolumn{4}{|c|}{ Related SDGs } \\
\hline & & & 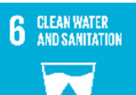 & 13 AUMAIIE & 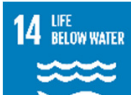 & 15 IfE \\
\hline $\begin{array}{l}\text { Shipping } \\
\text { exhaust } \\
\text { emissions }\end{array}$ & $\begin{array}{l}\text { Dangerous by-products: } \\
\text { SOx, NOx, black carbon, } \\
\text { ozone etc. }\end{array}$ & $\begin{array}{l}\text { Acid rain, soot formation, } \\
\text { climate-forcing actions etc. }\end{array}$ & $\checkmark$ & $\checkmark$ & & $\checkmark$ \\
\hline Oil spillage & $\begin{array}{l}\text { Accidental discharge of } \\
\text { oil from ships }\end{array}$ & $\begin{array}{l}\text { Increased mortality of } \\
\text { marine animals, } \\
\text { water pollution }\end{array}$ & $\checkmark$ & $\checkmark$ & $\checkmark$ & $\checkmark$ \\
\hline Noise pollution & $\begin{array}{l}\text { Ship noise over the } \\
\text { acceptable level }\end{array}$ & $\begin{array}{l}\text { Behavioural disturbances in } \\
\text { marine mammals }\end{array}$ & & & $\checkmark$ & \\
\hline Ship-strikes & $\begin{array}{l}\text { Collision of shipping } \\
\text { vessels with marine } \\
\text { animals }\end{array}$ & $\begin{array}{l}\text { Propeller lacerations, } \\
\text { massive trauma, } \\
\text { haemorrhage, broken bones } \\
\text { or death in marine } \\
\text { mammals }\end{array}$ & $\checkmark$ & & $\checkmark$ & \\
\hline \multirow{3}{*}{$\begin{array}{l}\text { Use of } \\
\text { icebreakers }\end{array}$} & Open water channels & Trapped marine animals & & & \multirow{3}{*}{$\checkmark$} & \multirow{3}{*}{$\checkmark$} \\
\hline & Increased ambient noise & $\begin{array}{l}\text { Marine animals' } \\
\text { behavioural disturbance }\end{array}$ & & & & \\
\hline & Higher fuel consumption. & Increased carbon emission & & & & \\
\hline
\end{tabular}

The Canadian Arctic is known to have some of the best air quality in the world [49]; an increase in shipping traffic could affect this. Currently, icebreaking operations are usually required to break, separate, or divert ice in ice-covered waters to ensure safe navigation for ships. A major impact of this is increased fuel usage. The most used form of fuel in marine engines is heavy fuel oil (HFO). According to van Luijk et al. [50], between 2010 and 2018, approximately $37 \%$ of the vessels (mostly bulk carriers, general cargo, and tanker ships) that travelled through the Canadian Arctic used HFO. Because the Canadian Arctic is currently not an emission control area, there are no sulphur restrictions on the grade of HFO allowed to be used by transiting ships. HFO has high nitrogen, sulphur, and ash content, thereby leading to significant levels of by-products of oxides of nitrogen, unburned hydrocarbons, carbon monoxides, ozone, and particulate matter into the atmosphere from the exhaust gas of the marine engine (see, [51,52]). When present in the air, these chemicals lead to air pollution and harm life in the proximity. For example, nitrogen oxides are a significant cause of acid rain and soot formation. Furthermore, black carbon and carbon dioxide emitted from ships are climate-forcing agents that could impact the radiative balance. Black carbon emissions could also increase the rate at which the sea ice melts. It is projected that ArSh emissions could contribute as much as $5 \%$ of the ambient ozone concentration and $5 \%$ to $20 \%$ of the ambient particulate matter concentration over a broad region of the Canadian Arctic as early as 2030 if measures are not put in place (see, [53]). To that end, the Canadian government has designated the Arctic as an emission control area for stack emissions [54]. The International Maritime Organization has directed the Pollution Prevention and Response Subcommittee to develop a plan to phase out usage of HFO by ships sailing through the Arctic [55]. These measures, if successfully implemented, could greatly reduce exhaust emissions, thereby maintaining the atmospheric quality in the Canadian Arctic.

Increased shipping also raises the chance of accidental oil spillage, which pollutes the water and creates a great danger to biodiversity. Some Arctic animals like seabirds, polar bears, and seal pups are particularly susceptible to oil, which reduces the insulating 
properties of their feathers or fur, thereby exposing them to extreme cold, leading to hypothermia or death. During early spring, pods of Narwhal migrate through the NWP and are vulnerable to both the impact on the environment, their feeding and breeding grounds, and potential collisions [56]. The National Oceanic and Atmospheric Administration [57] documented that the Exxon Valdez oil spill in Alaska in 1989 killed, among others, billions of salmon and herring eggs, about 250,000 seabirds, and 2800 sea otters; the restoration efforts are ongoing. The consequences of an oil spill, especially in an extremely cold environment, could affect the integrity of fisheries, marine mammals, seabirds, and the coastal wildlife leading to changes in their growth, reproduction, feeding, and motility. Furthermore, if oil spills in the Arctic are undetected or not treated, biologists theorize that the oil could remain for as long as 50 years due to its slow rate of degradation at near-zero temperatures. This would lead to an extended impact on the marine ecosystem [58]. Having a timely cleanup response to oil spills is therefore crucial. However, this also creates challenges due to natural freezing conditions and the fact that response personnel and equipment are usually remotely located. Furthermore, it would be difficult to organize an emergency response if the spill were to occur right before winter freeze-up.

Gautier et al. [59] estimated that more than $20 \%$ of the remaining undiscovered oil and gas is in the Arctic. As global demand for energy increases, it is likely that oil drilling activities will increase (depending on Arctic oil and gas policy at the time). Therefore, pertinent preventive measures need to be put in place, and oil spill responses should be efficiently implemented.

Increased ship traffic could lead to an increase in ambient noise levels [60]. Vessels traversing the NWP are audible as far as $100 \mathrm{~km}$ away due to the quiet soundscape of Arctic waters [19]. Therefore, it is necessary to assess the potential acoustic impacts of ship-sourced noise pollution, especially on animals in these waters, before this increase in noise level occurs. The 2016 NOAA report [61] suggests an increasing likelihood of behavioural effects on marine mammals for sound greater than a certain threshold decibel value. Other impacts include increased stress levels and habitat displacement, impacted prey/predator detectability, impaired communication, and navigation [19,62].

Halliday et al. [19] studied two Marine Protected Areas in the Canadian Arctic: The Tarium Niryutait Marine Protected Area and Anguniaqvua Niqiqyuam Marine Protected Area, which is home to marine animals such as bearded and ringed seals, as well as bowhead and beluga whales. Their study compares the noise propagation from vessels travelling through the Arctic to the behavioural sound threshold of marine mammals. It concludes that sound produced by icebreakers as close as $2 \mathrm{~km}$ away and tankers as far away as $52 \mathrm{~km}$ negatively affects marine mammals substantially. This implies that an influx of shipping traffic through the NWP would expose marine mammals to more noise pollution, thereby impacting the marine ecosystem.

More studies are required to fully understand the dynamics and what management plans could be put in place to effectively reduce the impact of shipping noise on marine mammals. Some mitigation and best practices recommended by the Arctic Marine Shipping Assessment 2009 report [63] include ship speed restrictions, rerouting to avoid congregation areas, and alternative designs of hulls and engines to make them quieter. As the water warms up, more marine animals will follow their food sources up the North Atlantic and directly into shipping lanes and to the NWP (for example the Right Whale following krill). Lessons can be learned from the Government of Canada's efforts to protect the North Atlantic Right Whale by adjusting fishing season times, seasonal closures, vessel traffic management measures, speed restrictions, and restricted access [64].

Vessel collision with marine mammals, referred to as ship strikes, is an increasing problem worldwide. Collisions generally result in massive trauma, hemorrhage, broken bones, and, in many cases, the eventual death of mammals [65]. The likelihood of ship strikes will be higher with increased shipping traffic. Among endemic Canadian Arctic marine mammals, the species presumed to be most at risk are beluga whales, ringed seals, narwhals, walruses, bowhead whales, bearded seals, and polar bears. Due to the gradual 
reduction in sea-ice cover, the population of one of the biggest predators in the Arctic, the killer whale, is increasing in certain areas [66]. Areas like Hudson Strait, Foxe Basin, and Hudson Bay have recorded exponentially increasing sightings of this predator [67]. An increase in ship strikes may cause a quicker extinction of some of these marine mammals.

Studies have shown that the speed at which a vessel is sailing when it strikes a large mammal is a key determinant of the severity of harm caused. Lower speeds increase the survival chances of a stricken whale significantly [66]. Some of these species aggregate in groups, making them more easily detectable by passing vessels. To protect vulnerable species, vessels should attempt to avoid areas where they are known to congregate or reduce their speed if traversing those areas is unavoidable.

The inadvertent transportation of invasive species to foreign waters can lead to the loss of native biological diversity. Aquatic invasive species threaten the structure and functioning of ecosystems [68]. They could also act as vectors or exhibit invasive traits, thereby posing threats to local marine mammals. Increases in ship traffic exacerbate this risk. The major means by which these organisms are transported include ballast water discharges and attachment to hulls of ships (hull fouling), shipping accidents and sinking, and movement of invasive species within sealift or resupply cargoes to Arctic communities. Thus, as the Canadian Arctic undergoes an influx of ship traffic, the threat of invasive species comes simultaneously. Researchers have attempted to model the pattern of movement of invasive species through various means. This makes it easier to effectively reduce invasion risks in the marine Arctic through methods like early detection, vector management, and rapid response [69].

Besides icebreakers causing noise pollution, the open-water channels left after their operations take time to freeze thereby disrupting the movement of animals over the ice. This leads to alteration in existing migratory patterns of land animals, such as caribou, which rely on sea ice for migration [70]. Moreover, animals that mistake these open channels for polynyas (ice openings that occur naturally) can become trapped deep within the water as the ice above freezes. Increased ship traffic may induce more ice-breaking activities, thereby leading to increased occurrences of this hazard.

In summary, an increase in shipping through the Canadian Arctic has potential benefits. It would reduce climate-threatening emissions by reducing fuel usage and carbon emissions. However, an array of possible local environmental impacts is apparent, ranging from the effects on marine animals and humans in the environment to sanitation. More research on each of the raised concerns is recommended, and necessary measures must be put in place to mitigate or prevent these hazards from becoming bigger issues before ArSh becomes more prominent. Ship traffic is growing steadily, and it is therefore important that best measures and practices are set as foundational guidelines for all shipping activities to ensure environmental imperatives. Table 3 is an effort to illustrate the extant literature in this area that summarizes our inference and interpretation of the environmental implications of ArSh and the related effects viewed from an SDGs lens. The key impacts of higher exhaust emissions, potential oil spillage and the impact on clean water and sanitation (UNSDG \#6) and climate pollution (UNSDG \#13) are presented. Table 3 also lists the impact of shipping strikes, noise pollution and the use of icebreakers on marine life and life on land (UNSDG \#14 and \#15). While the SDG frameworks have typically been studied and assessed using quantitative methodologies to arrive at percentage increases and changes (pollution levels, emissions, shipping strikes, etc.), we have used an inductive approach to review these studies and apply a qualitative lens to arrive at our inferences and interpretations.

\subsection{Implications for Social Sustainability}

The social pillar of QBL is rather difficult to assess because of its broad range of components, its quickly changing nature, and differing social conditions depending on where you are in the world. The social pillar is nevertheless an equally important component of QBL. Society and people play a major role in being the middle-ground contributors of sustainable supply chains [11,71]. Society is a complex and borderline-interchangeable concept that 
can have different meanings depending on the context and the writer [72]. This research views the social pillar of QBL as the social and physical characteristics of communities that uniquely define them and need to be preserved (c.f., $[73,74])$. At first glance, it may appear that an influx of Canadian ArSh would not create major social changes, but this is likely not the case. With sustainability being core to our study, this section analyzes the implications of Canadian ArSh on society. The related SDGs (recall Figure 1 and see [75]) are no poverty (\#1), zero hunger (\#2), good health and well-being (\#3), quality education (\#4), gender equality (\#5), affordable and clean energy (\#7), sustainable cities and communities (\#11), and peace, justice, and strong institutions (\#16). These SDGs involve many segments of society, with the broader social components that they encompass shown in Figure 5. If these social components are achieved, it will overall be a more successfully sustainable society. We elaborate on such factors as food security, health and well-being, and access to energy in attaining social sustainability and summarize their implications and relationships to SDGs in Table 4.

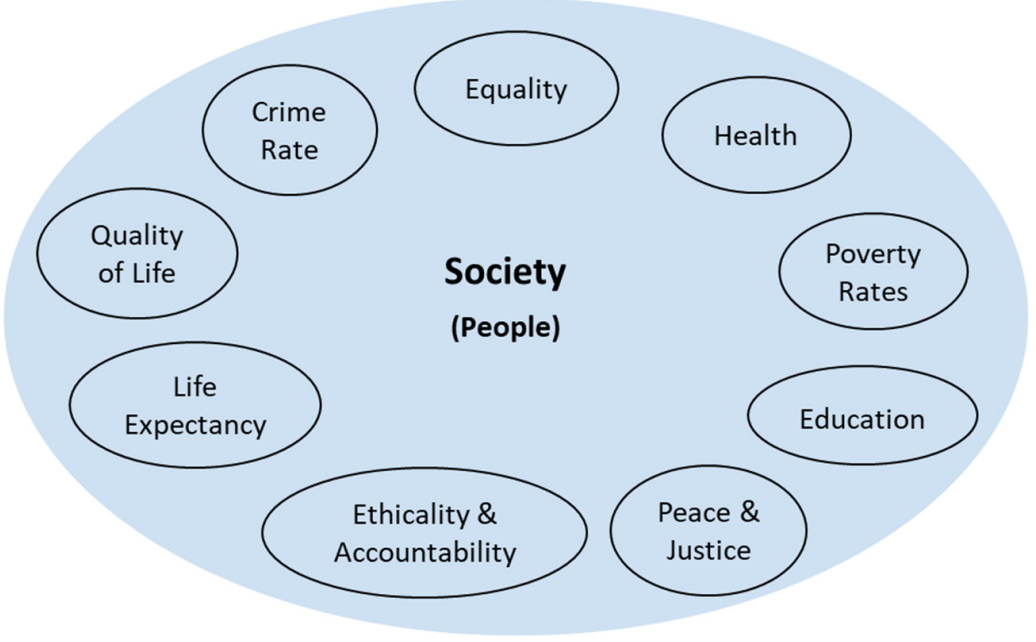

Figure 5. Broad social components that the UN SD societal goals encompass (based on [75]).

SDG \#2 aims to "end hunger, achieve food security and improved nutrition and promote sustainable agriculture" [25]. Although Canada is a developed and wealthy country, household food insecurity is nonetheless a major problem that impacts physical, mental, and social health. An unfortunate reality is that Canada's Arctic territories are the top three food-insecure regions in Canada (see Figure 6). For example, in 2017-2018, $57 \%$ of households in Nunavut were food insecure, and 79\% of the children there lived in food-insecure households [76]. Moreover, these numbers are projected to climb even higher amidst the COVID-19 pandemic [77].

A contributing factor to the food insecurity statistics is the cost of food in the Arctic. Fresh produce cannot be grown there most of the year, so communities rely on foods shipped over vast distances, inflating the price by up to 10 times the amount it would be in southern Canada [78]. An influx of ArSh could potentially help this issue in two ways. First, as more ships traverse Canada's Arctic, policy initiatives could be enacted to help bring produce while these ships are on their voyages to their final destinations. Secondly, an influx of shipping to the Arctic is projected to enhance infrastructural development in the communities, such as port developments, and reliable electricity (previously discussed in Section 3.1). Growth in these sectors could help reduce food prices. Pedersen [79] mentions how one prominent reason food is so expensive is because most of Nunavut is not connected to major electricity grids. As a result, generators must power the freezers to conserve the food, which inflates prices. Increased development (because of increased shipping) could decrease food prices, making food more accessible, resulting in less food insecurity. More diverse food choices could also be delivered, providing communities with necessary nutrients. 
Table 4. Summary of social implications of ArSh with relation to SDGs.

\begin{tabular}{|c|c|c|c|c|c|c|c|c|c|}
\hline \multirow[b]{2}{*}{$\begin{array}{l}\text { Factors } \\
\text { Considered }\end{array}$} & \multirow[b]{2}{*}{$\begin{array}{l}\text { Potential } \\
\text { Effects from ArSh }\end{array}$} & \multicolumn{8}{|c|}{ Related SDGs } \\
\hline & & 1 inoverr & 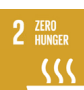 & 3 conyurith & 4 Matrit & 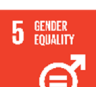 & 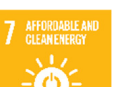 & 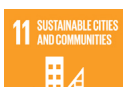 & 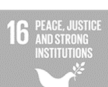 \\
\hline \multirow{2}{*}{$\begin{array}{l}\text { Food } \\
\text { security in the } \\
\text { Canadian } \\
\text { Arctic }\end{array}$} & $\begin{array}{l}\text { + More affordable } \\
\text { store-bought food. }\end{array}$ & \multirow[b]{2}{*}{$\checkmark$} & \multirow[b]{2}{*}{$\checkmark$} & \multirow[b]{2}{*}{$\checkmark$} & & & & \multirow[b]{2}{*}{$\checkmark$} & \\
\hline & $\begin{array}{l}\times \text { Impact hunting } \\
\text { methods. }\end{array}$ & & & & & & & & \\
\hline \multirow{2}{*}{$\begin{array}{l}\text { Impact on health \& } \\
\text { well-being of Arctic } \\
\text { communities. }\end{array}$} & $\begin{array}{l}\text { + More accessible } \\
\text { healthcare }\end{array}$ & \multirow{2}{*}{$\checkmark$} & \multirow{2}{*}{$\checkmark$} & \multirow{2}{*}{$\checkmark$} & \multirow{2}{*}{$\checkmark$} & & \multirow{2}{*}{$\checkmark$} & & \\
\hline & $\begin{array}{l}\times \text { Exacerbated } \\
\text { health effects. }\end{array}$ & & & & & & & & \\
\hline $\begin{array}{l}\text { Energy availability } \\
\text { and accessibility } \\
\text { issues }\end{array}$ & $\begin{array}{l}\text { + More affordable, } \\
\text { reliable, and } \\
\text { accessible energy. }\end{array}$ & $\checkmark$ & $\checkmark$ & $\checkmark$ & $\checkmark$ & & $\checkmark$ & $\checkmark$ & \\
\hline \multirow{2}{*}{$\begin{array}{l}\text { Inclusion and } \\
\text { criminal safety in the } \\
\text { Arctic } \\
\text { communities }\end{array}$} & $\begin{array}{l}\text { + More inclusive } \\
\text { society for Northern } \\
\text { communities } \\
+ \text { Higher safety }\end{array}$ & & & \multirow{2}{*}{$\checkmark$} & & \multirow{2}{*}{$\checkmark$} & & \multirow{2}{*}{$\checkmark$} & \multirow{2}{*}{$\checkmark$} \\
\hline & $\begin{array}{l}\times \text { Increased traffic } \\
\text { and criminal } \\
\text { behaviour }\end{array}$ & & & & & & & & \\
\hline $\begin{array}{l}\text { Peaceful Industry } \\
\text { and Interaction in } \\
\text { Arctic communities }\end{array}$ & $\begin{array}{l}+\times \text { Peaceful } \\
\text { cooperation or } \\
\text { conflicting disputes } \\
\text { (case dependent) }\end{array}$ & & & $\checkmark$ & & $\checkmark$ & & $\checkmark$ & $\checkmark$ \\
\hline
\end{tabular}

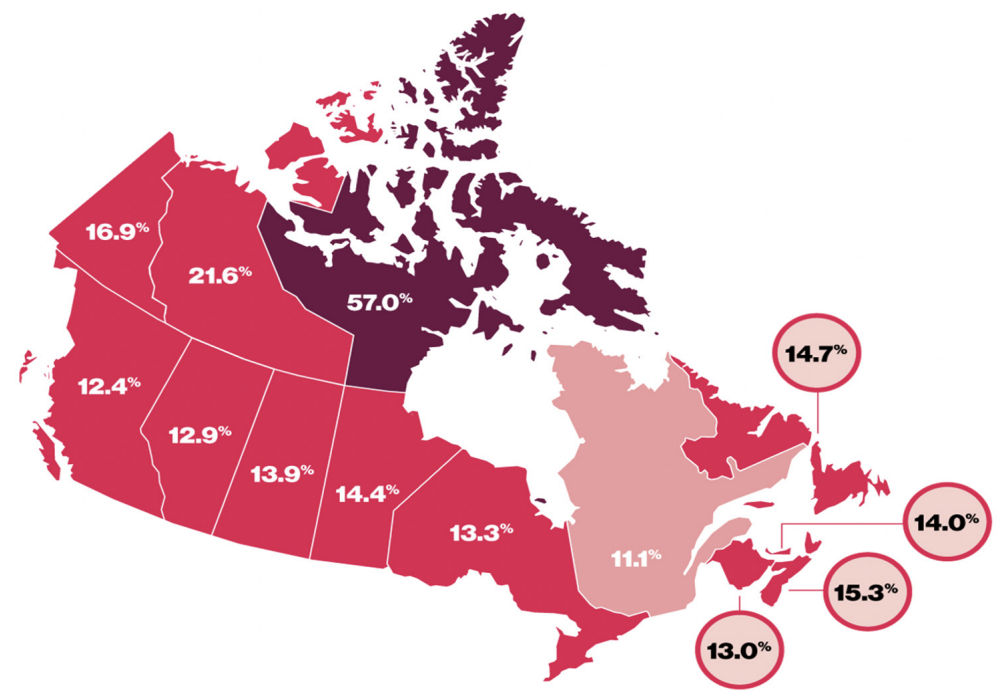

Figure 6. Percentage of population considered food insecure in each Canadian province or territory (source: [76]).

Arguably, Canadian ArSh could kick-start more development that may improve storepurchased food security. However, marine traffic may negatively impact traditional Inuit hunting and fishing. The Inuit have relied on the land and waters for food for generations, but an increase in ship traffic through their territory will result in hunting and fishing becoming more unpredictable and difficult [70]. This will impact the Inuit from food security and financial standpoint (by being forced to purchase more store-bought food), as well as from a cultural standpoint (discussed in Section 3.4). As a result, increased shipping could help mitigate issues of inaccessible store-bought food but create issues for hunted food. 
SDG\#3 is to "Ensure healthy lives and promote well-being for all at all ages" [25]. Despite efforts to improve the current physical and mental health conditions of Arctic Canadian community members, they are still amongst the worst in Canada [80]. Due to low income, less access to education, mental unwellness, food insecurity, poor availability of health services, and worse living conditions, the average life expectancy of Inuit in the Arctic is over ten years lower than the Canadian average [81]. Moreover, Inuit Nunangat (the Inuit name for their homeland of land, water, and ice) communities have considerably higher rates of poor health and well-being compared to Canadian averages (see Figure 7).

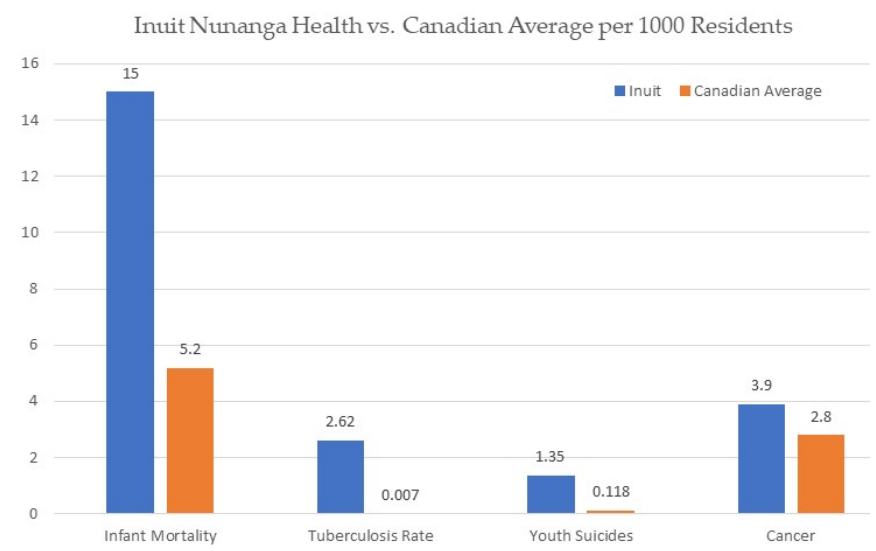

Figure 7. Inuit health and well-being statistics compared to entire Canadian averages (data sources: $[81,82])$.

Figure 7 demonstrates the poorer health and well-being rates of Inuit compared to Canadian averages, primarily derived from lack of healthcare accessibility, lack of nutrients and food security, and isolation depression [81]. Although few studies are done on this topic, ArSh would likely have both positive and negative implications for this social dilemma. Mental distress, early-life adversity (such as aggressive behaviours and childhood sexual abuse), substance abuse, and lack of available mitigation options are the primary cause of the high number of Inuit suicides [83]. An influx of ArSh could mitigate these factors in two ways. First, a result of more ship traffic is increased development, new avenues of employment during the shipping seasons, and income (discussed in Section 3.1). As a result, more effective healthcare such as therapy, medication, regular check-ups, etc. will likely be accessible. Secondly, more enforcement and justice policies will likely be implemented in the communities because of economic development derived from ArSh.

On the other hand, negative health impacts can be caused by high levels of ship traffic itself. Vessels release an array of atmospheric pollutants such as carbon dioxide, nitrogen oxide, particulate matter, and sulphur oxides. Despite the environmental impacts, these emissions can impact human health by creating nose and throat irritations, respiratory conditions, chronic obstructive pulmonary diseases, cancers, and asthma, among others [84]. Moreover, the dumping of sewage, oils, waste, bilge water, and other such pollutants into the ocean is harmful. Once these waste materials are in the marine environment, they are consumed and absorbed by marine life, which could impact northern communities in two ways. First, if the spills are so severe that it kills marine life, communities will have less food to hunt, leading to health impacts. Secondly, the chemicals that marine life absorbs can bioaccumulate and transfer to humans once they are consumed, leading to potential digestive and neurological disorders [85]. Presently, there are strict pollution control policies in the Arctic (such as the Arctic Water Pollution Prevention Act), and shipping is too minimal for this to yet have major impacts, but if it undergoes projected growth, this threat will become more prevalent. Furthermore, increased shipping is directly correlated with increased fatalities from accidents on board. Between the years 2014 and 2020, there were a total of 550 fatalities recorded from accidents [85]. Communities in the 
North may not be used to dealing with such shipping fatalities, possibly causing mental and physical distress.

SDG\#7 aims to "Ensure access to affordable, reliable, sustainable, and modern energy for all" [25]. The Canadian Arctic is severely lacking accessible and affordable energy and power. Community members in the Northwest Territories and Nunavut pay over 30 cents per kilowatt-hour, while the Canadian average is 13.8 cents if the North is excluded. This is due to low population densities, remote regions, and geographic constraints. As a result, local small-scale power generation facilities are almost all diesel-fueled, and most homes are heated by expensive fuel oils [86]. This impacts Northern communities financially and creates social impacts from noisy generators, toxic emissions, and rolling blackouts [87].

As ArSh increases in the coming decades, the demand for more power and energy will become evident. Ships that call at Arctic ports would create demand for fuel and energy, possibly leading to more government subsidization. To that end, for instance, the deep-water port in northern Manitoba has been undergoing development [88]. The subsequent development and income that will likely come together (see Section 3.1) may result in communities being put on more accessible power grids or developing local clean energy initiatives. Already underway are the plans for accessible clean energy projects to create affordable and sustainable energy in the Canadian Arctic [87]. This section is partly speculative, but educated projections show that accessible power and energy will be readily available because of more shipping.

SDG \#11 is to "Make cities and human settlements inclusive, safe, resilient, and sustainable" [25]. In terms of inclusion, Canadian Arctic communities are already beginning to see positive changes from Arctic shipping. Canada officially adopted in 2016 the United Nations Declaration of the Rights of Indigenous Peoples (UNDRIP) [89], and recent social movements that allow Indigenous peoples to have more autonomy with ongoing projects in or near their lands and water have drawn attention to the matter. As a result, Inuit communities have been more included as primary stakeholders for partaking in ArSh operations. This has been made clear with the development of organizations like the Inuit Guardians Program and the Nunavut Impact Review Board that give the Inuit autonomy in governing Arctic development projects. Furthermore, the Canadian Coast Guard and Transport Canada have undertaken projects in recent years to ensure that communities are included in risk mitigation and response operations in the event of shipping accidents [90]. These inclusion programs will likely evolve and continue as shipping increases in the Arctic, where Indigenous Peoples consultation will be imperative in the process (c.f. [91,92]). There is still more work to be done with community inclusion, but so far it has yielded some promising results.

Regarding the safety component, it could go either way. On the one hand, if foreign vessels are transiting the NWP, the federal government would have increased security and military presence in the region. As a result, more ArSh will allow for security personnel and better law enforcement in the communities. On the other hand, more vessel traffic could increase criminal activity such as drug smuggling, piracy, terrorism, kidnapping, etc. Between the years 2017 and 2019, seizures of cocaine aboard commercial ships more than tripled, mainly from the growth of ship size and tight time schedules, allowing for most of the cargo to go unchecked [93]. With projections of the NWP to be ice-free most of the year by 2050, criminals could sense an opportunity in this. Arctic communities might have to deal with the safety impacts of ship-based criminal activity.

"Promote peaceful and inclusive societies for sustainable development, provide access to justice for all and build effective, accountable and inclusive institutions at all levels" is the stated SDG \#16 [25]. The relationship between northern communities and industry over the years has evolved into overall peaceful and collaborative interactions. However, there is still conflict between the stakeholder groups. For example, the Mary River iron mine in northern Baffin Island has experienced ongoing protests from nearby community members due to environmental concerns [94]. Although most of the protests in the Arctic have been peaceful thus far, it is nonetheless damaging to social well-being for all actors involved. 
Arctic communities, governments, and industries have collaborated effectively in the past in achieving mutually beneficial outcomes. However, there are concerns and brewing tensions with stakeholder groups about projected shipping plans, which may impede social development. To create collaborative and peaceful social opportunities in the Arctic, Canada has invested $\$ 190$ million to construct multi-use buildings, food processing units, and harbours. An influx of shipping to the communities is necessary to make these ambitions a reality. If executed properly, this will create inclusion of the Arctic on both Canadian and international playing fields, which could eliminate disputes. Projected increases in ArSh may provide both opportunities and setbacks for social sustainability. Increasing social development of the Canadian Arctic will benefit all Canadians and has been a crucial component of the Canadian government's Northern Policy Framework [54]. Collaborative stakeholder consultations and sustainable development are paramount for Canada to experience the benefits of ArSh and mitigate the weaknesses.

\subsection{Implications for Cultural Sustainability}

Before dissecting Indigenous cultural implications of Arctic shipping, it is first critical to understand what culture and culturally significant areas are. Culture is a broad, multidimensional concept that includes cultural assets, world views, and cultural practices; Satterfield et al. [95] (p. 105) state culture to be a "nontrivial problem for any environmental management regime". Thus, cultural values are complex, dynamic, and social constructs that contain both material and immaterial dimensions [96]. Derived from culture is the concept of culturally significant areas, with the primary objectives of solidifying the spatial scale into what is culturally important for a person or group of people [97]. For simplicity in this paper, the concept of "culture" is viewed as both tangible and intangible places, objects, and social components that are special for the Inuit people, due to historical importance, behaviour, livelihoods, norms, beliefs, and rituals.

Recognizing the implications that trans-ArSh along the NWP will have on Indigenous communities and cultures is fundamental for sustainable development. Inuit Nunangat is the area of Canada's Arctic affiliated with the coastlines, comprising a population of just over 60,000, of which approximately $85 \%$ are of Inuit descent and inhabit the Western Arctic, Central Arctic, Northern Quebec, and Northern Labrador. The Inuit have utilized the Arctic Ocean and its sea ice for generations, and that continues today. This is evidenced by all but three of the 53 communities in Inuit Nunangat being located along the coastline [98]. Inuit communities rely on the neighboring waterways and sea ice as vital forms of transport, access to subsistence hunting grounds, and spiritual zones, thereby making the marine Arctic a culturally significant area [99].

Without proper management frameworks, an influx of shipping will likely have profound negative impacts on Inuit culture including an unpredictable shift of traditional hunting grounds because of noise pollution (see Figure 8). Inuit communities rely heavily on the local environment for subsistence hunting [80], as survival hunts strictly for themselves and their families [100]. Subsistence hunting has been a vital tradition for the Inuit for generations, resulting in seasonal food security and its position as an important part of Inuit culture. The Inuit hunt beluga whale, narwhal, Arctic char, seal, and other marine mammals to sustain themselves for upcoming winter seasons and have designated annual hunts that have spiritual significance [70]. Much of the traditional hunting knowledge (migration patterns, seasonal harvest cycles, hunting methods) has been passed down for generations, further increasing its cultural significance [80].

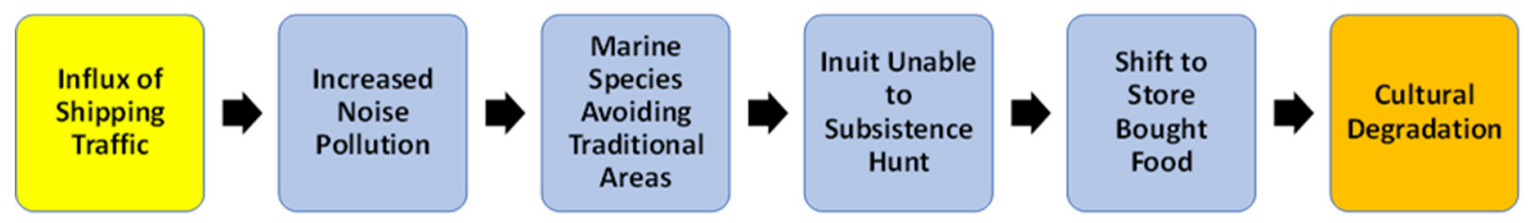

Figure 8. Process of cultural degradation from noise pollution. 
Halliday et al. [19] and Inuit Tapiritt Kanatami [80] have reported on the impact of ArSh on the hunting times and patterns, while Dawson et al. [70] have discussed the impact of noise pollution on the marine species. This, therefore, poses the threat of Inuit communities turning away from traditional hunting methods and purchasing overpriced store food, taking a toll on communities both culturally and financially. If the NWP opens to more transpolar shipping, likely this impact will exponentially worsen with more ship traffic, possibly altering some components of Inuit culture permanently.

Due to the archipelagic nature of the Canadian Arctic, sea ice plays a crucial role in Inuit culture, acting as a highway across their lands and waters, allowing them access to crucial hunting grounds [99]. It acts as a vital piece of infrastructure to carry out cultural traditions and to rid themselves of cabin fever [101]. The warming of the Arctic due to climate change is becoming more evident, especially in the Eastern and Southern Arctic regions, taking a toll on the sea ice that Inuit communities rely on. While sea ice is seen as a chokepoint or an unwanted obstacle for the shipping industry, Inuit see it as a means of physically connecting them to food, their livelihoods, and culture [99]. This is a conflict of interest that may become more evident as shipping through the NWP accelerates, and it could become another example of where capitalism's pursuit of accumulation puts negative pressure and influence on Indigenous ways of life [102,103]. In addition to Inuit reliance, land species (that are culturally significant to the Inuit) rely on sea ice for migration. Community members of Cambridge Bay, Nunavut, have noted that an influx of shipping has disrupted the sea ice that caribou use to migrate south from Victoria Island to mainland Canada [37]. Inuit partake in annual caribou hunts that have been passed down for generations and are now beginning to be impacted because of sea ice deterioration from ship traffic, further conflicting with cultural sustainability.

In many Inuit communities, ArSh lanes run adjacent to Inuit transport routes between islands. For example, in Figure 9 displayed is such a conflicting area between shipping lanes and Inuit transport with traditional sled over sea ice. The Inuit use traditional sled trails (month-dependent, seen as orange lines) from their communities in northern Baffin Island to travel north to Devon Island to access hunting and fishing grounds [104]. The primary NWP shipping route intersects with the traditional sled trails across the ice. Depending on the timing, this leaves Inuit travel routes inaccessible.

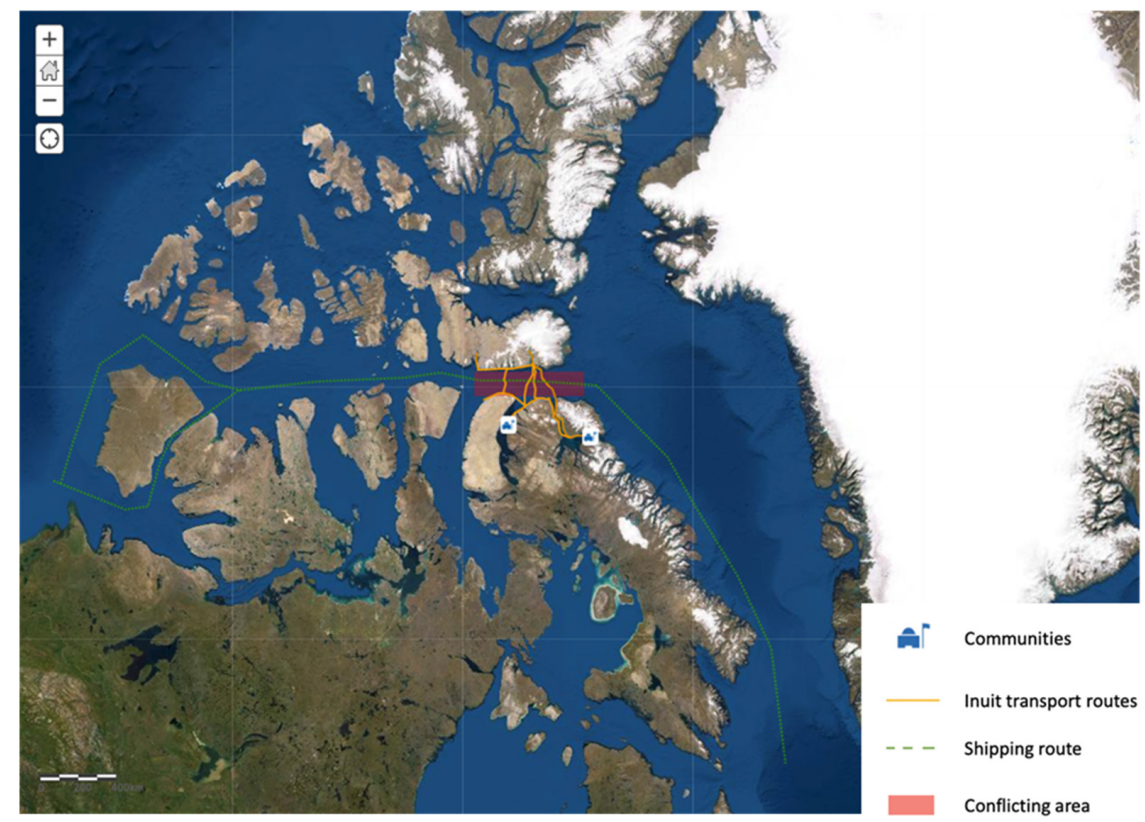

Figure 9. The intersection of NWP shipping route with traditional Inuit sled trails from Pond Inlet and Arctic Bay (based on $[99,105])$ 
Furthermore, there is a threat of this process accelerating and becoming a positive feedback loop of more shipping and its consequences on Inuit cultural loss. We propose and show that causal loop in Figure 10. As previously mentioned, the Canadian Arctic is already experiencing more shipping, with projected increases in the coming decades. As shipping increases, sea ice breaks will inevitably follow depending on the time of year. Unwanted sea ice breaks result in the inaccessibility of hunting areas and Inuit transport routes. Consequently, communities are at threat of having to shy away from traditional methods, leading to possible cultural deterioration. Article 8(2a) of UNDRIP (perhaps the most important legally binding policy for this situation) declares, "States shall provide effective mechanisms for prevention of, and redress for: any action which has the aim or effect of depriving them of their integrity as distinct peoples, or of their cultural values or ethnic identities" [89] (p. 10). Article 8(2a) could thereby protect Inuit from cultural degradation caused by increased shipping [106]. However, some community members argue that their culture is already being deteriorated by current shipping numbers [70]. This means the shipping industry could potentially argue that marine traffic is not impacting any cultural values because their culture is already being impacted. Such a flawed argument could leverage more shipping if it is seen as not impacting culture (due to culture already being affected since the beginning stages of shipping) and continue the dangerous feedback loop, reiterating the process. At present, this feedback is relatively theorized but built on real cultural impacts, UNDRIP policies, and educated speculation. It is paramount that these Indigenous concerns are being heard in stakeholder consultations to ensure that Inuit culture can be sustained, which some argue is already beginning to fade [107]. A future study could look specifically at the actual cultural deterioration based on metrics that can more accurately determine the loss of subsistence hunting, the numbers of marine and land animals impacted (decreased populations as a result of Sea Ice Break), and erosion of cultural and traditional practices as a direct result of increased ArSh and thus allow us to test the proposed causal feedback loop.

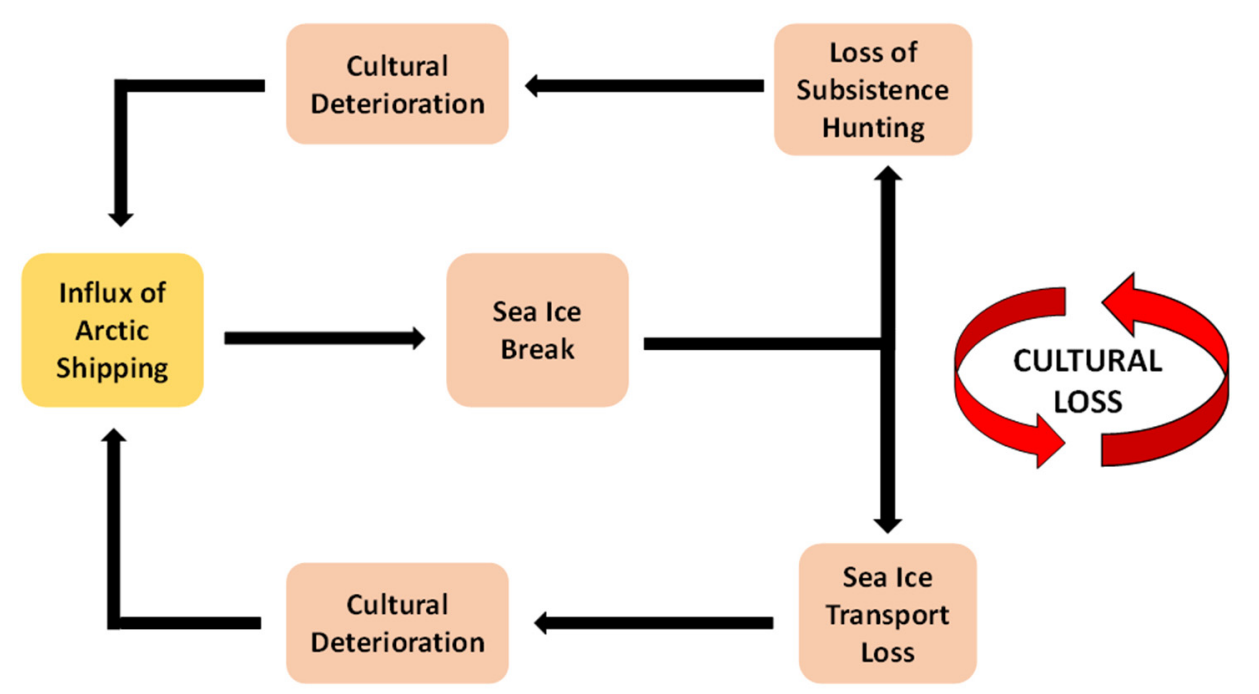

Figure 10. The possible positive feedback loop of Inuit cultural deterioration caused by an influx of shipping in Canada's Arctic.

It is likely that Arctic communities will experience economic benefits from increased shipping. In 2017, just over half of Inuit aged 15 or older in Inuit Nunangat were employed in a wage economy [108]. People tend to migrate to where there are money and job opportunities. As a result, northern communities may see urbanization, population growth, industrialization, and modernization. The population of the three territories that make up the Canadian Arctic is growing at a faster rate than the rest of Canada, with Nunavut leading the way with 12\% growth; the capital city (Iqaluit) grew 15.5\% between 2011 and 2016 [109]. Nunavut's population is projected to reach 54,000 by $2043,14,000$ more than 
the 2021 census [110]. Although this may increase the number of Inuit partaking in a wage economy (which could benefit them financially), it could consequently impact their culture. If non-Indigenous people immigrate in high numbers from other parts of the world for employment opportunities due to what ArSh could provide, the Inuit people could face the threat of cultural assimilation.

Although the implications previously discussed are negative impacts, positive cultural impacts from Canadian ArSh may also emerge. As the industry grows in the Arctic, the Inuit have had the opportunity to be a more prominent stakeholder and make their voices heard compared to recent decades. Arguably, the systemic reason for the neglect of Indigenous concerns is primarily from a lack of education that results in ignorance of the topic [111]. Simply put, the average Canadian southerner is not heavily educated on the Inuit culture due to poor education systems and because of the vast physical distance between one another, resulting in a lack of knowledge. A large percentage of the Canadian population will never venture into the Arctic in their lifetimes. As the Canadian Arctic opens up to a wider audience of people, more southerners will learn about the Inuit people and their way of life. As people become educated, more may be done to preserve Indigenous cultures. Indigenous culture is a critical component of the Canadian Arctic, and effective measures must be taken to ensure its preservation and sustainability. In Table 5, we summarize the aforementioned factors with their impact on cultural sustainability (by the example of Inuit culture) and the SDGs that we posit as related.

Table 5. Summary of Indigenous cultural implications of ArSh considered in the analysis.

\begin{tabular}{ll}
\hline Factors Considered & Potential Effects from Arctic Shipping \\
\hline Noise pollution from ships & $\begin{array}{l}\text { × Impacts Inuit traditional hunting methods } \\
\text { culturally significant for Arctic communities. }\end{array}$ \\
\hline $\begin{array}{l}\text { Ship-sourced sea ice } \\
\text { deterioration }\end{array}$ & $\begin{array}{l}\text { B Breaks sea ice that Inuit use for transport, } \\
\text { hunting, spiritual significance, \& way of life. }\end{array}$ \\
\hline $\begin{array}{l}\text { The feedback loop of } \\
\text { cultural loss }\end{array}$ & $\begin{array}{l}\times \text { Possible ongoing positive feedback loop of } \\
\text { how increased shipping will cause more } \\
\text { cultural loss, and then continue the cycle. }\end{array}$ \\
\hline $\begin{array}{l}\text { Cultural assimilation } \\
\text { Arctic commigration and population growth to } \\
\text { opportunities brought by shipping) could } \\
\text { result in cultural assimilation. }\end{array}$ & $\checkmark \checkmark$ \\
$\begin{array}{l}\text { Increased knowledge of } \\
\text { cultural preservation }\end{array}$ & $\begin{array}{l}\text { + More immigration to Arctic communities } \\
\text { could result in more knowledge of the Inuit } \\
\text { people. Thus, more effort could be made to } \\
\text { preserve their culture. }\end{array}$ \\
\hline
\end{tabular}

The Global North has been dominated by a colonial capitalist culture that is presently reconciling with past wrongs of how we have marginalized, oppressed, and negatively affected Indigenous cultures. Thousands of years before capitalism, Indigenous cultures lived interconnected in relationship to the land and seascapes, understanding the reciprocity and interdependence with these processes. Indigenous cultures can be seen as matriarchal or matristic cultures, which value cooperation, respect for all other beings, the continual regeneration of the web of life, cocreation, and sacredness of land, sea, and air systems [103]. With climate change upon us, this relational approach of living in harmony with the biosphere is more critical than ever; humankind's future depends on it. Considering these perspectives, Indigenous and sustainability science frameworks (e.g., SDGs) have great 
value in combining techniques and approaches for sustaining resilient land and seascapes for desired futures [112].

The SDGs and the 2030 Agenda are steeped in human rights and recognize fairness, prosperity, and sustainability on a universal level. Adopting an ambitious agenda for fostering human well-being within planetary boundaries and connecting it with the relationality and communality perspectives of Indigenous cultures make for a strong and resilient blueprint to co-create synergies to embrace climate change strategies. Policies that consider decent work and economic growth (SDG \#8), sustainable cities and communities (SDG 11), peace, justice, and strong institutes SDG \#16), and partnerships for the sustainable goals (SDG \#17) mesh with Indigenous sustainability knowledge frameworks. Modeling pathways towards a sustainable future will require policies that consider not only sustainable scientific frameworks but also Indigenous knowledge frameworks.

\subsection{A Recap of $Q B L$ Analysis}

The previous QBL analysis demonstrates that an influx of shipping through the Canadian Arctic will have an array of implications for the QBL pillars, some positive and some negative. To summarize the implications and display them as an overarching whole, an interaction matrix is presented that demonstrates whether Canadian ArSh can be categorized as complementary, evenly conflicting and complementary, mostly conflicting, or conflicting to the four QBL pillars (Figure 11).

\section{QBL Pillars}

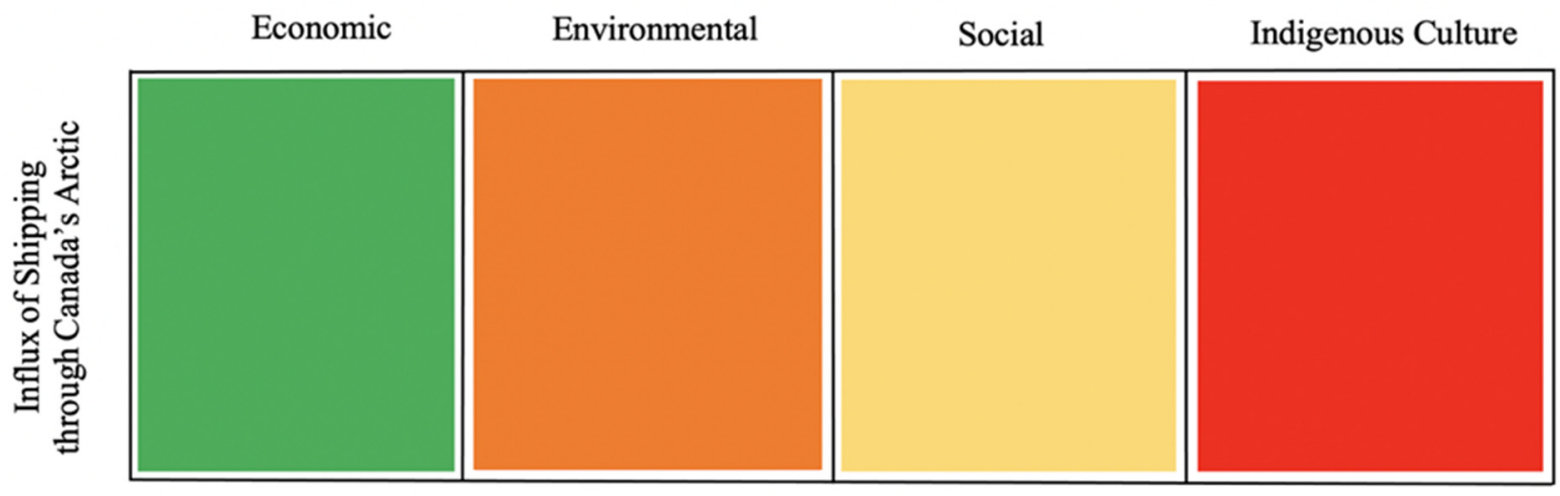

Figure 11. Interaction matrix demonstrating how each QBL pillar interacts with Canadian ArSh.

Regarding the economic pillar, there are some disadvantages that ArSh will produce. However, most of the implications on a macro scale are positive, so it is listed as green, representing a complementary interaction. The environmental pillar is difficult to assess. On the one hand, GHG emissions would likely decrease due to shorter shipping distances. On the other hand, it is difficult to determine how much of a climatic difference this would make on the global scale. Many uncertainties and studies suggest we are already at a point of no return with emissions from other sectors [113]. Furthermore, the direct environmental impacts an influx of shipping will have on the Arctic environment (with more studies supporting this claim being released at an accelerating rate) somewhat outweigh the emissions reduction. Therefore, we categorize ArSh as a mostly conflicting interaction with the environmental pillar. There is a relatively even split of both positive and negative implications for the social pillar. For this reason, it is listed as evenly conflicting and complementary. Case-by-case scenarios will need to be analyzed for social sustainability. 
Lastly, there are large threats of Inuit cultural deterioration as both direct and indirect results of increased Arctic shipping. As a result, it is listed as a conflicting interaction.

This information demonstrates the large conflicts of interest when it comes to ArSh. What might be beneficial or complementary for one stakeholder group may be conflicting for another. For example, there may be economic benefits for shipping firms and trade nations, but heavy consequences for the northern communities and the marine life that inhabit the region. As a result, increased involvement from the government and third parties is needed to monitor the sector to ensure fair trade-offs and sustainable shipping practices. Thus, emphasis should be placed on the environmental and Indigenous cultures sector (the sectors of higher conflict) of QBL to achieve adequate sustainability across all pillars.

Finally, we emphasize that the interaction results in Figure 11 are all but a general hypothesis to be utilized cautiously on a case-by-case basis. For example, the type of shipping (e.g., a transit container shipping from East Asia to Europe without stopping vs. a destination shipping to or from Arctic locales) and the type of freight transported (e.g., nonperishable foods vs. fuel) would have varying effects (benefits, drawbacks) on SDGs and QBL.

\section{Discussion and Implications}

ArSh routes are currently not as popular as traditional ones, yet there has been a significant increase in the past decade. The literature suggests it is likely there will be an even greater increase in the coming years as sea ice levels continue to decrease because of climate change. As discussed in this paper, the influx of ArSh will cause numerous issues that need to be addressed for sustainability purposes. For this reason, it is critical that each of the four pillars of the QBL (economy, environment, society, and culture) is considered and that measures are taken for risk mitigation. The relations between the QBL and the SDGs (see Figure 2) enable further opportunities to develop frameworks and lay the groundwork for formal decision models for transportation infrastructure and routing decisions. Undoubtedly, discussion of the implications of climate change will continue in public, academic, and policy-making arenas. The case of ArSh is all but one that climate change has brought about.

We posit that business possibilities around the Arctic routes will cause contention among multiple stakeholders. Besides considerations of the international and political competitive forces, decisions as to how to proceed will depend on the decision-maker. Transportation and trade policies in the Arctic should include all the stakeholder or community members (government, communities, trading partners, and transport industry-shippers, consignees, carriers), and consensus needs to be reached before investing in transport infrastructure and vessels. As we pointed out in our exploratory analysis of each pillar of the QBL, transportation decisions in the Arctic should align with the UN Sustainability Development Goals.

Another implication of our study is the fact that the colonial capitalist system has placed Indigenous peoples outside society, thus suppressing and marginalizing their voices. Therefore, especially as business models evolve towards QBL pillars, explicitly integrating SDGs in those pillars in ways that such vital factors as preserving culture, maintaining peace, and creating a just society should not be ignored. Although it is harder to quantify and measure the progress of those factors, developing integrative frameworks such as Fisher et al. [114] describe is the first step towards building more inclusive and equitable decision-making processes.

Another consideration is the extreme and creative value that diversity offers to a system. Policymakers and community members alone cannot use old hegemonic approaches to tackle the rapidly changing complexity of our world, like the grand challenge of climate change, using single worldviews. We need new ways of thinking to resolve new emerging challenges. Employing strategies that imbue and espouse a diversity of cultural, economic, societal, and environmental perspectives is the idea of a "pluriverse" (see, [103]) which 
offers innovations and new ways of thinking towards sustainable futures. Modelling pathways towards a sustainable future require conscious efforts of integrating and considering the SDGs framework and climate action in our strategies of bringing products and services to the marketplace. Through this approach, it can enable multiple worldviews to tackle the challenges and needs of various stakeholders and community members involved in the Arctic region with human rights and sustainability at the forefront.

\section{Conclusions and Future Research}

This paper examines from the QBL perspective (cultural, economic, environmental, and societal) the impact of climate change on Arctic routes and transportation. The findings of this holistic analysis are exhibited in an interaction matrix. Because of the complex and multi-faceted issues and uncertainties surrounding the Arctic, it may be overly simplistic to have a definite clear-cut answer to the question of whether to support Arctic transportation now or not. Rather, with this study, we display a spectrum of issues pertinent to the sustainability of future decisions related to Arctic influx. More specific recommendations, based on available data and simulation, could provide some guidance for each of the stakeholders. One assumption we make in this study is that all the partnering countries in the Arctic region have a continuing interest in implementing the SDGs. Because the overview in this study is confined to published scholarly literature and news, mainly from a Canadian perspective, more data on Arctic influx can be collected through structured surveys with the stakeholder groups (not only in Canada, but also in other countries in the Arctic Circle-Russia, the U.S., Norway, Finland, Sweden, Denmark, and Iceland) about their opinions and concerns on the impact of climate change and the increased use of Arctic transportation routes. This would be a natural next step for the continuation of our research on the Arctic. We posit that in the case of shipping in the Canadian Arctic, there exists scholarship to draw on to assess if and how shipping in its various forms can contribute to or detract from the 17 SDGs the United Nations has laid out. The answer is complicated, but if we assume that many types of shipping are likely to increase, our analysis points to a few places where appropriate planning and policy interventions can make a big difference.

Today's conjecture is more than about balancing accumulation and efficiency with resource scarcity. As Altvater [115] (p. 141) states, " ... the planet's carrying capacity and resilience in the face of runaway climate change is now under siege". Five years out from the Paris 2015 agreement on climate action (2030 Agenda), when reviewing our progress towards the goals, the facts are alarming and sobering. With a narrow timeline to 2030, there is a risk of not being able to achieve the Paris climate targets; more than ever it is recognized how urgent and vital it is to synergize climate action, SDGs, and QBL objectives [116]. Humankind is now witnessing the detrimental effects of climate change, with one example being melting Arctic ice and rising sea levels that create flooding and havoc for global coastal communities. From a capitalistic lens, we cannot just use a narrow focus towards accumulation opportunities with the opening of the Arctic. Moreover, we also need to weigh the full consequences of our policies and actions from a systematic and long-term perspective. Furthermore, we need to continue to research and understand social-ecological systems using valuable quantitative measurements, and we need to explore systems and processes from a relationality and communality perspective, intertwining Indigenous knowledge frameworks and multiple worldviews with scientific knowledge frameworks in the pursuit of sustainable futures. This enables us as humans to position ourselves as 'humans of the planetary system' - not sensing ourselves as disconnected and outside of the biosphere but instead recognizing that we are interdependent, reciprocal, and intertwined in our planet. In considering policy and strategy towards future opportunities in the Arctic, there needs to be a transformation towards sustainability that better aligns policies with climate action, SDGs, and frameworks like the QBL pillars. Synergistic approaches such as these can offer desired futures that reconcile and embrace human well-being with planetary flourishing. 
There remain various open venues for research on the influx of ArSh and sustainability. It is critical that each of the four QBL pillars is considered in policymaking and in setting long-term governmental mandates, and that measures are taken for risk mitigation. To that end, one research direction is to develop data-driven, multi-objective analytical models where decision-makers determine what the specific impacts of increased ArSh will be and what can be done to ensure sustainability. Such decision support models would inevitably include, among others, environmental impact and possible risk response assessments, collaborative stakeholder analysis, government subsidy levels for transport infrastructure, and constraints on preserving impacted Indigenous cultures. Over the past decade, there has been a substantial increase in academic research on Arctic shipping, and as it becomes more prevalent, this trend will likely continue. As the negative impacts of climate change surface more frequently, and as pressure increases on businesses to perform more sustainably, how does a transportation company acquire a social license to operate in the Arctic routes? What additional sustainability metrics, from a holistic QBL perspective, need to be developed and tracked for Arctic shipping for sustainable supply chain logistics? This is another avenue of research we plan to explore next. We hope this study will spur further dialogue on Arctic research where SDGs are considered in synergistic combination with QBL.

Author Contributions: Conceptualization, S.J.T. and M.A.Ü.; methodology, S.J.T., A.P.R., I.O.O. and M.A.Ü.; investigation, S.J.T., A.P.R. and I.O.O.; writing-original draft preparation, S.J.T., A.P.R., I.O.O. and K.A.W.; writing-review and editing, M.A.Ü., K.A.W. and B.S.; visualization, S.J.T., I.O.O. and A.P.R.; supervision, M.A.Ü.; funding acquisition, M.A.Ü. and B.S. All authors have read and agreed to the published version of the manuscript.

Funding: This research was funded by the Centre for Research in Sustainable Supply Chain Analytics (CRSSCA) at Dalhousie University, Canada (CRSSCA \#68513-210001-SCR).

Data Availability Statement: Not applicable.

Conflicts of Interest: The authors declare no conflict of interest.

\section{References}

1. Copland, L.; Dawson, J.; Johnston, M.E.; Pizzolato, L.; Howell, S.E.; Pelot, R.; Etienne, L.; Matthews, L.; Parsons, J. Climate Change Adaptation Strategies and Policy Options for Arctic Shipping. A Report Prepared for Transport Canada; Geography, Environment and Geomatics-Publications: Ottawa, ON, Canada, 2017; Available online: https:/ /www.arcticcorridors.ca/wp-content/uploads / 2020/07/Climate-Change-Adaptation-Strategies-sm.pdf (accessed on 3 May 2021).

2. Overland, J.; Wang, M. When will the summer Arctic be nearly sea ice free? Geophys. Res. Lett. 2013, 40, 2097-2101. [CrossRef]

3. Dawson, J.; Copland, L.; Mussells, O.; Carter, N. Shipping Trends in Nunavut 1990-2015: A Report Prepared for the Nunavut General Monitoring Program. Ottawa, Canada and Iqaluit, Nunavut. 2017. Available online: https:/ /www.arcticcorridors.ca/ wp-content/uploads/2019/12/NGMP-Shipping-Report_APR2018_WEB.pdf (accessed on 10 June 2021).

4. Dawson, J.; Carter, N.; van Luijk, N.; Parker, C.; Weber, M.; Cook, A.; Grey, K.; Provencher, J. Infusing Inuit and local knowledge into the Low Impact Shipping Corridors: An adaptation to increased shipping activity and climate change in Arctic Canada. Environ. Sci. Policy 2020, 105, 19-36. [CrossRef]

5. Marsh Risk Management Research. Arctic Shipping: Navigating the Risks and Opportunities. 2014. Available online: https: //www.safety4sea.com/wp-content/uploads/2014/09/pdf/Arctic_Shipping_Lanes_MRMR_August_2014_US.pdf (accessed on 10 May 2021).

6. Lu, D.; Park, G.; Choi, K.; Oh, S. An economic analysis of container shipping through Canadian Northwest Passage. Int. J. e-Navig. Marit. Econ. 2014, 1, 60-72. [CrossRef]

7. DeRepentigny, P.; Jahn, A.; Holland, M.M.; Smith, A. Arctic Sea Ice in Two Configurations of the CESM2 During the 20th and 21st Centuries. J. Geophys. Res. Oceans 2020, 125, e2020JC016133. [CrossRef]

8. King, H. What Is the Northwest Passage? Climate Change Has Opened a Shipping Route through the Canadian Arctic. Geology News and Information. 2021. Available online: https://geology.com/articles/northwest-passage.shtml (accessed on 15 March 2021).

9. Powell, N. Northern Exposure: Can the Northwest Passage Live up to Its Billing as a Maritime Superhighway? Financial Post. 2018. Available online: https:/ / financialpost.com/news/economy/northern-exposure-can-the-northwest-passage-live-up-toits-billing-as-a-maritime-superhighway (accessed on 17 March 2021).

10. Cheaitou, A.; Faury, O.; Cariou, P.; Hamdan, S.; Fabbri, G. Economic and environmental impacts of Arctic shipping: A probabilistic approach. Transp. Res. Part D Transp. Environ. 2020, 89, 102606. [CrossRef] 
11. Ülkü, M.A.; Engau, A. Sustainable Supply Chain Analytics. In Industry, Innovation and Infrastructure; Leal Filho, W., Azul, A.M., Brandli, L., Lange Salvia, A., Wall, T., Eds.; Encyclopedia of the UN Sustainable Development Goals; Springer: Cham, Switzerland, 2021; pp. 1123-1134. [CrossRef]

12. Lavissière, A.; Sohier, R.; Lavissière, M.C. Transportation systems in the Arctic: A systematic literature review using textometry. Transp. Res. Part A Policy Pract. 2020, 141, 130-146. [CrossRef]

13. Corbett, J.J.; Lack, D.A.; Winebrake, J.J.; Harder, S.; Silberman, J.A.; Gold, M. Arctic shipping emissions inventories and future scenarios. Atmos. Chem. Phys. 2010, 10, 9689-9704. [CrossRef]

14. Smith, L.C.; Stephenson, S.R. New trans-Arctic shipping routes navigable by midcentury. Proc. Natl. Acad. Sci. USA 2013, 110, E1191-E1195. [CrossRef]

15. Buixadé Farré, A.; Stephenson, S.R.; Chen, L.; Czub, M.; Dai, Y.; Demchev, D.; Efimov, Y.; Graczyk, P.; Grythe, H.; Keil, K.; et al. Commercial Arctic shipping through the Northeast Passage: Routes, resources, governance, technology, and infrastructure. Polar Geogr. 2014, 37, 298-324. [CrossRef]

16. Miller, W.; Ruiz, G. Arctic shipping and marine invaders. Nat. Clim. Chang. 2014, 4, 413-416. [CrossRef]

17. Ghosh, S.; Rubly, C. The emergence of Arctic shipping: Issues, threats, costs, and risk- mitigating strategies of the Polar Code. Aust. J. Marit. Ocean Aff. 2015, 7, 171-182. [CrossRef]

18. Champalle, C.; Ford, J.D.; Sherman, M. Prioritizing Climate Change Adaptations in Canadian Arctic Communities. Sustainability 2015, 7, 9268-9292. [CrossRef]

19. Halliday, W.; Insley, S.J.; Hilliard, R.C.; de Jong, T.; Pine, M.K. Potential impacts of shipping noise on marine mammals in the western Canadian Arctic. Mar. Pollut. Bull. 2017, 123, 73-82. [CrossRef] [PubMed]

20. Theocharis, D.; Pettit, S.; Rodrigues, V.S.; Haider, J. Arctic shipping: A systematic literature review of comparative studies. J. Transp. Geogr. 2018, 69, 112-128. [CrossRef]

21. Ng, A.K.; Andrews, J.; Babb, D.; Lin, Y.; Becker, A. Implications of climate change for shipping: Opening the Arctic seas. Wiley Interdiscip. Rev. Clim. Change 2018, 9, e507. [CrossRef]

22. Downing, J. An Evaluation of the Impact of Shipping on Arctic Indigenous Peoples. The Henry M. Jackson School of International Studies. 2019. Available online: https:/ /jsis.washington.edu/news/an-evaluation-of-the-impact-of-shipping-on-arcticindigenous-peoples/ (accessed on 17 March 2021).

23. Rockström, J.; Steffen, W.; Noone, K.; Persson, Å.; Chapin, E., III; Lambin, E.; Foley, J. Planetary boundaries: Exploring the safe operating space for humanity. Ecol. Soc. 2009, 14, 32. Available online: https://www.ecologyandsociety.org/vol14/iss2/art32/ (accessed on 20 May 2021). [CrossRef]

24. Merriam-Webster. Dictionary Entry for "Culture". 2021. Available online: https://www.merriam-webster.com/dictionary/ culture (accessed on 15 February 2021).

25. United Nations. The 17 Goals. Department of Economic and Social Affairs. 2021. Available online: https://sdgs.un.org/goals (accessed on 20 March 2021).

26. Pradhan, P.; Costa, L.; Rybski, D.; Lucht, W.; Kropp, J.P. A systematic study of sustainable development goal (SDG) interactions. Earth's Future 2017, 5, 1169-1179. [CrossRef]

27. van Zanten, J.A.; van Tulder, R. Improving companies' impacts on sustainable development: A nexus approach to the SDGS. Bus. Strat. Environ. 2021, 30, 3703-3720. [CrossRef]

28. Scrimgeour, F.; Iremonger, C. Maori Sustainable Economic Development in New Zealand: Indigenous Practices for the Quadruple Bottom Line; University of Waikato: Hamilton, New Zealand, 2004.

29. Walters, F.; Takamura, J. The decolonized quadruple bottom line: A framework for developing indigenous innovation. Wicazo Rev. 2015, 30, 77-99. [CrossRef]

30. Pizzirani, S.; McLaren, S.J.; Forster, M.E.; Pohatu, P.; Porou, T.T.W.; Warmenhoven, T.A. The distinctive recognition of culture within LCSA: Realising the quadruple bottom line. Int. J. Life Cycle Assess. 2018, 23, 663-682. [CrossRef]

31. Budsaratragoon, P.; Jitmaneeroj, B. Measuring causal relations and identifying critical drivers for corporate sustainability: The quadruple bottom line approach. Meas. Bus. Excel. 2019, 23, 292-316. [CrossRef]

32. Webster, J.; Watson, R.T. Analyzing the past to prepare for the future: Writing a literature review. MIS Q. 2002, 26, xiii-xxiii.

33. Snyder, H. Literature review as a research methodology: An overview and guidelines. J. Bus. Res. 2019, 104, 333-339. [CrossRef]

34. Dawson, J. Arctic shipping: Future prospects and ocean governance. In The Future of Ocean Governance and Capacity Development; International Ocean Institute-Canada, Ed.; e-book, Brill I Nijhoff: Leiden, The Netherlands, 2018; pp. 484-489. [CrossRef]

35. Pizzi, S.; Rosati, F.; Venturelli, A. The determinants of business contribution to the 2030 agenda: Introducing the SDG reporting score. Bus. Strategy Environ. 2021, 30, 404-421. [CrossRef]

36. Ceballos, G.; Ehrlich, P.R.; Dirzo, R. Biological annihilation via the ongoing sixth mass extinction signaled by vertebrate population losses and declines. Proc. Natl. Acad. Sci. USA 2017, 114, E6089-E6096. [CrossRef] [PubMed]

37. Carter, N.A.; Dawson, J.; Knopp, J.; Joyce, J.; Weber, M.; Kochanowicz, Z.; Mussells, O. Arctic Corridors and Northern Voices: Governing Marine Transportation in the Canadian Arctic (Cambridge Bay, Nunavut Community Report); University of Ottawa: Ottawa, ON, Canada, 2018; Available online: https://ruor.uottawa.ca/handle/10393/37325 (accessed on 1 January 2022).

38. Government of Canada. Implications for Economic Development and Adaptation within Key Sectors. Available online: https://www.nrcan.gc.ca/changements-climatiques/impacts-adaptation/implications-economic-development-andadaptation-within-key-sectors/10273 (accessed on 30 November 2015). 
39. Weather Atlas. Arctic Bay, Canada-Detailed Climate Information and Monthly Weather Forecast. 2021. Available online: https:/ / www.weather-atlas.com/en/canada/arctic-bay-climate (accessed on 28 March 2021).

40. Herrmann, T. Shipping through the Northwest Passage: A Policy Brief. 2019. Available online: https://jsis.washington.edu/ news / shipping-through-the-northwest-passage-a-policy-brief/ (accessed on 15 March 2021).

41. Huebert, R. Climate Change and Canadian Sovereignty in the Northwest Passage. 2001. Available online: https://journalhosting. ucalgary.ca/index.php/cpmss/article/view/36337 (accessed on 1 April 2021).

42. Transport Canada. List of Canada Port Authorities. Government of Canada. 2020. Available online: https://tc.canada.ca/en/ marine-transportation/ports-harbours-anchorages/list-canada-port-authorities (accessed on 10 April 2021).

43. Government of Canada. Debate and Direction of Arctic Shipping Policy. Transport Canada. 2010. Available online: https: / / tc.canada.ca/en/marine-transportation/arctic-shipping/debate-direction-arctic-shipping-policy (accessed on 15 May 2021).

44. Mills, R. Canada's Warming Arctic-Implications. Education Canada. 2020. Available online: https://www.mining.com/web/ canadas-warming-arctic-implications / (accessed on 6 March 2021).

45. Fedi, L.; Etienne, L.; Faury, O.; Rigot-Muller, P.; Stephenson, S.; Cheaitou, A. Arctic navigation: Stakes, benefits and limits of the POLARIS system. J. Ocean Technol. 2018, 13, 54-67.

46. Hjelle, H.M.; Fridell, E. When is short sea shipping environmentally competitive? In Environmental Health-Emerging Issues and Practice; Oosthuizen, J., Ed.; InTechOpen: Rijeka, Croatia, 2012; pp. 3-20.

47. Zeng, Q.; Lu, T.; Lin, K.-C.; Yuen, K.F.; Li, K.X. The competitiveness of Arctic shipping over Suez Canal and China-Europe railway. Transp. Policy 2020, 86, 34-43. [CrossRef]

48. Weregeland, T. Arctic Shipping Routes-Cost Comparisons with Suez. Arctic Knowledge Hub. 2010. Available online: http: / / www.arctis-search.com/Arctic+Shipping+Routes+-+Cost+Comparisons+with+Suez (accessed on 11 March 2021).

49. IQAir. Air Quality in the World. 2021. Available online: https://www.iqair.com/world-air-quality (accessed on 10 April 2021).

50. van Luijk, N.; Dawson, J.; Cook, A. Analysis of heavy fuel oil use by ships operating in Canadian Arctic waters from 2010 to 2018. FACETS 2020, 5, 304-327. [CrossRef]

51. Granier, C.; Niemeier, U.; Jungclaus, J.H.; Emmons, L.; Hess, P.; Lamarque, J.-F.; Walters, S.; Brasseur, G.P. Ozone pollution from future ship traffic in the Arctic northern passages. Geophys. Res. Lett. 2006, 33, L13807. [CrossRef]

52. Schröder, C.; Reimer, N.; Jochmann, P. Environmental impact of exhaust emissions by Arctic shipping. Ambio 2017, 46, 400-409. [CrossRef]

53. Gong, W.; Beagley, S.R.; Cousineau, S.; Sassi, M.; Munoz-Alpizar, R.; Ménard, S.; Racine, J.; Zhang, J.; Chen, J.; Morrison, H.; et al. Assessing the impact of shipping emissions on air pollution in the Canadian Arctic and northern regions: Current and future modelled scenarios. Atmos. Chem. Phys. 2018, 18, 16653-16687. [CrossRef]

54. Government of Canada. Canada's Arctic and Northern Policy Framework. Crown-Indigenous Relations and Northern Affairs Canada. 2019. Available online: https:/ / www.rcaanc-cirnac.gc.ca/eng/1560523306861/1560523330587 (accessed on 3 May 2021).

55. United States-Canada Joint Arctic Leaders Statement. 2016. Available online: pm.gc.ca/en/news/statements/2016/12/20 / united-states-canada-joint-arctic-leaders-statement (accessed on 10 April 2021).

56. Hauser, D.; Stern, H.; Laidre, K. As Arctic Ship Traffic Increases, Narwhals and Other Unique Animals Are at Risk. 2018. Available online: https:/ / theconversation.com/as-arctic-ship-traffic-increases-narwhals-and-other-unique-animals-are-at-risk-99733 (accessed on 20 December 2021).

57. NOAA-National Oceanic and Atmospheric Administration. Damage Assessment, Remediation, and Restoration Program-Exxon Valdez. 2020. Available online: https:/ / darrp.noaa.gov/oil-spills/exxon-valdez (accessed on 10 December 2021).

58. Eger, K.M. Effects of Oil Spills in Arctic Waters. 2010. Available online: http://www.arctis-search.com/Effects+of+Oil+Spills+in+ Arctic+Waters (accessed on 11 March 2021).

59. Gautier, D.L.; Bird, K.J.; Charpentier, R.R.; Grantz, A.; Houseknecht, D.W.; Klett, T.R.; Moore, T.E.; Pitman, J.K.; Schenk, C.J.; Schuenemeyer, J.H.; et al. Assessment of Undiscovered Oil and Gas in the Arctic. Science 2009, 324, 1175-1179. [CrossRef] [PubMed]

60. McDonald, M.A.; Hildebrand, J.A.; Wiggins, S.M. Increases in deep ocean ambient noise in the Northeast Pacific west of San Nicolas Island, California. J. Acoust. Soc. Am. 2006, 120, 711-718. [CrossRef] [PubMed]

61. NOAA-National Oceanic and Atmospheric Administration. Takes of Marine Mammals Incidental to Specified Activities, Taking Marine Mammals Incidental to Site Characterization Surveys off the Coast of Massachusetts. 2016. Available online: https: / / www.federalregister.gov / documents/2016/04/05/2016-07712/takes-of-marine-mammals-incidental-to-specifiedactivities-taking-marine-mammals-incidental-to-site (accessed on 15 March 2021).

62. Rolland, R.M.; Parks, S.E.; Hunt, K.E.; Castellote, M.; Corkeron, P.J.; Nowacek, D.P.; Kraus, S.D. Evidence that ship noise increases stress in right whales. Proc. R. Soc. B Biol. Sci. 2012, 279, 2363-2368. [CrossRef] [PubMed]

63. AMSA. Arctic Marine Shipping Assessment by Arctic Council, Second Printing. 2009. Available online: https://oaarchive.arcticcouncil.org/handle/11374/54 (accessed on 20 June 2021).

64. Government of Canada. Government of Canada Continues to Help Protect North Atlantic Right Whales. 2021. Available online: https:/ / www.canada.ca/en/fisheries-oceans/news/2021/11/government-of-canada-continues-to-help-protect-northatlantic-right-whales.html (accessed on 30 January 2022).

65. Conn, P.B.; Silber, G.K. Vessel speed restrictions reduce risk of collision-related mortality for North Atlantic right whales. Ecosphere 2013, 4, 1-16. [CrossRef] 
66. Hauser, D.D.W.; Laidre, K.L.; Stern, H.L. Vulnerability of Arctic marine mammals to vessel traffic in the increasingly ice-free Northwest Passage and Northern Sea Route. Proc. Natl. Acad. Sci. USA 2018, 115, 7617-7622. [CrossRef]

67. Higdon, J.W.; Ferguson, S.H. Loss of Arctic sea ice causing punctuated change in sightings of killer whales (Oricinus orca) over the past century. Ecol. Appl. 2009, 19, 1365-1375. [CrossRef]

68. Goldsmit, J.; Archambault, P.; Chust, G.; Villarino, E.; Liu, G.; Lukovich, J.V.; Barber, D.G.; Howland, K.L. Projecting present and future habitat suitability of ship-mediated aquatic invasive species in the Canadian Arctic. Biol. Invasions 2018, 20, 501-517. [CrossRef]

69. Chan, F.T.; Stanislawczyk, K.; Sneekes, A.C.; Dvoretsky, A.; Gollasch, S.; Minchin, D.; David, M.; Jelmert, A.; Albretsen, J.; Bailey, S.A. Climate change opens new frontiers for marine species in the Arctic: Current trends and future invasion risks. Glob. Chang. Biol. 2019, 25, 25-38. [CrossRef]

70. Dawson, J.; Carter, N.A.; Joyce, J.; Ogilvie, A.; Weber, M. Arctic Corridors and Northern Voices: Governing Marine Transportation in the Canadian Arctic (Pond Inlet, Nunavut Community Report); University of Ottawa: Ottawa, ON, Canada, 2018; Available online: https:/ / uor.uottawa.ca/handle/10393/37271 (accessed on 21 April 2021).

71. Currie, B.A.; French, A.D.; Ülkü, M.A. Sustainability, Big Data, and Consumer Behavior: A Supply Chain Framework. In Big Data Analytics in Supply Chain Management, 1st ed.; Rahimi, I., Gandomi, A.H., Fong, S.J., Ülkü, M.A., Eds.; CRC Press: Boca Raton, FL, USA, 2021; pp. 109-132.

72. Mondal, P. Society: Sociologists Views, Characteristics and Definitions. 2018. Available online: https:/ /www.yourarticlelibrary. $\mathrm{com} /$ society/society-sociologist-views-characteristics-and-definitions/35064 (accessed on 10 March 2021).

73. Eizenberg, E.; Jabareen, Y. Social Sustainability: A New Conceptual Framework. Sustainability 2017, 9, 68. [CrossRef]

74. Awan, U.; Kraslawski, A.; Huiskonen, J. Governing interfirm relationships for social sustainability: The relationship between governance mechanisms, sustainable collaboration, and cultural intelligence. Sustainability 2018, 10, 4473. [CrossRef]

75. Folke, C.; Biggs, R.; Norström, A.V.; Reyers, B.; Rockström, J. Social-ecological resilience and biosphere-based sustainability science. Ecol. Soc. 2016, 21, 41. [CrossRef]

76. PROOF-Food Insecurity Policy Research. Household Food Insecurity in Canada. 2018. Available online: https:/ proof.utoronto ca/food-insecurity/\#: \{\}:text=In\%202017\%2D18\%2C\%201\%20in,living\%20in\%20food\%2Dinsecure\%20households (accessed on 20 March 2021).

77. Tsui, E. COVID-19's Impact on the Administration of Justice in Canada's Arctic. The Arctic Institute. 2020. Available online: https:/ / www.thearcticinstitute.org/covid-19-impact-administration-justice-canadas-arctic/ (accessed on 20 March 2021).

78. Garfield, L. Food Prices Are Insanely High in Rural Canada, Where Ketchup Costs $\$ 14$ and Sunny D Costs $\$ 29$. Business Insider. Available online: https://www.businessinsider.com/food-prices-high-northern-canada-2017-9 (accessed on 21 February 2021).

79. Pedersen, K. Millions of Dollars in Grocery Subsidies Haven't Lessened Food Insecurity in Canada's North. Eye on the Arctic. 2019. Available online: https:// www.rcinet.ca/eye-on-the-arctic/?s=millions+of+dollars+in+grocery (accessed on 20 May 2021).

80. Inuit Tapiriit Kanatami. Inuit Perspective on the Northwest Passage Shipping and Marine Issues. Nilliajut 2. 2017. Available online: https://www.itk.ca/wp-content/uploads/2018/01/NilliajutTextPages_Draftv4_english_web.pdf (accessed on 1 July 2021).

81. Inuit Tampiritt Kanatami. Social Determinants of Inuit Health in Canada. 2014. Available online: https://www.itk.ca/wpcontent/uploads/2016/07/ITK_Social_Determinants_Report.pdf (accessed on 1 July 2021).

82. Canadian Cancer Society. Cancer Statistics at a Glance. 2021. Available online: https://action.cancer.ca/en/research/cancerstatistics / cancer-statistics-at-a-glance\#: \{\}:text=115\%2C800\%20Canadian $\% 20$ men $\% 20$ will $\% 20 \mathrm{be}$, die $\% 20$ from $\% 20 \mathrm{cancer} \% 20$ every\%20day (accessed on 28 March 2021).

83. Chachamovich, E.; Kirmayer, L.J.; Haggarty, J.M.; Cargo, M.; McCormick, R.; Turecki, G. Suicide among Inuit: Results from a Large, Epidemiologically Representative Follow-Back Study in Nunavut. Can. J. Psychiatry 2015, 60, 268-275. [CrossRef] [PubMed]

84. ECCC-Environment Climate Change Canada. Air Pollution: Drivers and Impacts. Government of Canada. 2020. Available online: https:/ / www.canada.ca/en/environment-climate-change/services/environmental-indicators/air-pollution-driversimpacts.html (accessed on 5 March 2021).

85. EMSA-European Maritime Safety Agency. Annual Overview of Marine Casualties and Incidents. 2021. Available online: http:/ / www.emsa.europa.eu/newsroom/latest-news/download/6955/4266/23.html (accessed on 25 December 2021).

86. Natural Resources Canada. Energy Fact Book 2020-2021. 2021. Available online: https://www.nrcan.gc.ca/sites/nrcan/files/ energy/energy_fact/energy-factbook-2020-2021-English.pdf (accessed on 20 May 2021).

87. WWF-World Wildlife Fund. The True Cost of Fuel in the Arctic. Pembina Final Report. 2020. Available online: https://wwf.ca/ wp-content/uploads/2020/06/The-True-Cost-of-Fuel-in-the-Arctic_Pembina-Final-Report.pdf (accessed on 10 January 2022).

88. Murphy, J. Is the Arctic Set to Become a Main Shipping Route? BBC News. 2018. Available online: https://www.bbc.com/news/ business-45527531 (accessed on 10 March 2021).

89. UNDRIP - United Nations Declaration on the Rights of Indigenous Peoples. 2007. Available online: https://www.un.org/ development/desa/indigenouspeoples/wp-content/uploads/sites/19/2018/11/UNDRIP_E_web.pdf (accessed on 1 June 2021).

90. Transport Canada. A Review of Canada's Ship-Source Spill Preparedness and Response: Setting the Course for the Future, Phase 2-Requirements for the Arctic and for Hazardous and Noxious Substances Nationally. Transport Canada Tanker Safety Expert Panel: 1-112. 2014. Available online: https:/ / publications.gc.ca/site/eng/9.629646/publication.html (accessed on 1 May 2021). 
91. Doyle-Bedwell, P.; Cohen, F.G.; Parson, E.A. Aboriginal peoples in Canada: Their role in shaping environmental trends in the twenty-first century. In Governing the Environment; Doyle-Bedwell, P., Cohen, F.G., Eds.; University of Toronto Press: Toronto, ON, Canada, 2016; pp. 169-206.

92. Pictou, S. The origins and politics, campaigns and demands by the international fisher peoples' movement: An Indigenous perspective. Third World Q. 2018, 39, 1411-1420. [CrossRef]

93. Paris, C. Global Shipping Faces Troubling New Smuggling Questions. Wall Street Journal. 2020. Available online: https://www. wsj.com/articles/global-shipping-faces-troubling-new-smuggling-questions-11578330634 (accessed on 10 December 2021).

94. Thompson, J. Baffinland Blockade Cost Estimated \$14 million. Nunatsiaq News. 2021. Available online: https://nunatsiaq.com/ stories/article/baffinland-blockade-cost-estimated-to-be-14-million/ (accessed on 30 March 2021).

95. Satterfield, T.; Gregory, R.; Klain, S.; Roberts, M.; Chan, K.M. Culture, intangibles and metrics in environmental management. J. Environ. Manag. 2013, 117, 103-114. [CrossRef]

96. Stephenson, J. The cultural values model: An integrated approach to values in landscapes. Landsc. Urban Plan. 2008, 84, 127-139. [CrossRef]

97. Gee, K.; Kannen, A.; Adlam, R.; Brooks, C.; Chapman, M.; Cormier, R.; Fischer, C.; Fletcher, S.; Gubbins, M.; Shucksmith, R.; et al. Identifying culturally significant areas for marine spatial planning. Ocean Coast. Manag. 2017, 136, 139-147. [CrossRef]

98. Oceans North Conservation Society. Canada's Arctic Marine Atlas; Oceans North Conservation Society: Ottawa, ON, Canada, 2018.

99. Aporta, C.; Kane, S.C.; Chircop, A. Shipping corridors through the Inuit homeland. Limn J. 2018, 10, 50-65.

100. Siddons, S. How Subsistence Hunting Works. HowStuffWorks. 2009. Available online: https:/ /adventure.howstuffworks.com/ outdoor-activities/hunting/alternative-methods/subsistence-hunting.htm (accessed on 20 March 2021).

101. Andersen, C.; Rayner-Canham, G. Sea Ice: Essential for Northern Survival. 2019. Available online: https://uwaterloo.ca/chem1 3-news-magazine/february-2019/feature/sea-ice-essential-northern-survival (accessed on 5 April 2021).

102. Moore, J.W. Capitalism in the Web of Life: Ecology and the Accumulation of Capital; Verso Books: London, UK, 2015.

103. Escobar, A. Pluriversal Politics: The Real and the Possible; Duke University Press: Durham, NC, USA, 2020.

104. Aporta, C. The Trail as Home: Inuit and Their Pan-Arctic Network of Routes. Hum. Ecol. 2009, 37, 131-146. [CrossRef]

105. Halliday, W.D.; Dawson, J. Ship-Source Noise Modeling from 2015-2018 in the Kitikmeot Region and Lancaster Sound (Northwest Passage), Nunavut. 2021. Available online: https://www.espg.ca/wp-content/uploads/2021/03/Halliday_Dawson_ShipNoise_Modeling_in_Kitikmeot_and_Lancaster_Sound_final.pdf (accessed on 30 January 2022).

106. Wilt, J. Implementing UNDRIP Is a Big Deal for Canada. Here's What You Need to Know. The Narwhal. 2017. Available online: https://thenarwhal.ca/implementing-undrip-big-deal-canada-here-s-what-you-need-know/ (accessed on 1 April 2021).

107. QIA. A New Approach to Economic Development in Nunavut. Qikiqtani Inuit Association. 2018. Available online: https: //www.qia.ca/wp-content/uploads/2018/02/Asukuluk-QIA-Economic-Development-ENG-2018-02-27-v3-1.pdf (accessed on 2 April 2021).

108. Arriagada, P.; Bleakney, A. Inuit Participation in the Wage and Land-Based Economies in Inuit Nunangat. Statistics Canada. 2019. Available online: https: / /www150.statcan.gc.ca/n1/pub/89-653-x/89-653-x2019003-eng.htm (accessed on 2 April 2021).

109. Coppes, M. Canada's North is Growing. High North News. 2017. Available online: https://www.highnorthnews.com/en/ canadas-north-growing (accessed on 3 March 2021).

110. Nunatsiaq News. Nunavut's Population Could Reach 54,000 by 2043, StatCan Says. Nunatsiaq News. 2019 . Available online: https: / / nunatsiaq.com/stories/article/nunavuts-population-could-reach-54000-by-2043-statcan-says/ (accessed on 17 March 2021).

111. Krasovitski, M. Meaningful Education on Indigenous Peoples and Cultures Must Start at Schools. The Varsity. 2019. Available online: https:/ / thevarsity.ca/2019/03/16/meaningful-education-on-indigenous-peoples-and-cultures-must-start-at-schools / (accessed on 20 March 2021).

112. Johnson, J.T.; Howitt, R.; Cajete, G.; Berkes, F.; Louis, R.P.; Kliskey, A. Weaving Indigenous and sustainability sciences to diversify our methods. Sustain. Sci. 2016, 11, 1-11. [CrossRef]

113. Aengenheyster, M.; Feng, Q.Y.; van der Ploeg, F.; Dijkstra, H.A. The point of no return for climate action: Effects of climate uncertainty and risk tolerance. Earth Syst. Dyn. 2018, 9, 1085-1095. [CrossRef]

114. Fisher, J.; Arora, P.; Chen, S.; Rhee, S.; Blaine, T.; Simangan, D. Four propositions on integrated sustainability: Toward a theoretical framework to understand the environment, peace, and sustainability nexus. Sustain. Sci. 2021, 16, 1125-1145. [CrossRef] [PubMed]

115. Altvater, E. The capitolocene, or, geoengineering against capitalism's planetary boundaries. In Anthropocene or Capitalocene? Nature, History, and the Crisis of Capitalism; Moore, J.W., Ed.; PM Press: Oakland, CA, USA, 2016; pp. $138-152$.

116. Sörgel, B.; Kriegler, E.; Weindl, I.; Rauner, S.; Dirnaichner, A.; Ruhe, C.; Popp, A. A sustainable development pathway for climate action within the UN 2030 Agenda. Nat. Clim. Change 2021, 11, 656-664. [CrossRef] 